\title{
Water Budget for the lao Area, Island of Maui, Hawaii
}

By Patricia J. Shade

U.S. GEOLOGICAL SURVEY

Water-Resources Investigations Report 97-4244

Prepared in cooperation with the MAUI COUNTY DEPARTMENT OF WATER SUPPLY

Honolulu, Hawaii 


\section{U.S. DEPARTMENT OF THE INTERIOR \\ BRUCE BABBITT, Secretary}

U.S. GEOLOGICAL SURVEY

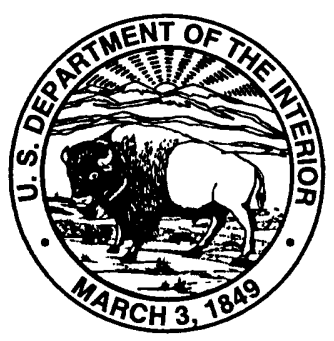

Mark Schaefer, Acting Director

The use of firm, trade, and brand names in this report is for identification purposes only and does not constitute endorsement by the U.S. Geological Survey.

For additional information write to:

District Chief

U.S. Geological Survey

677 Ala Moana Blvd., Suite 415

Honolulu, HI 96813
Copies of this report can be purchased from:

U.S. Geological Survey

Branch of Information Services

Box 25286

Denver, CO 80225-0286 


\section{CONTENTS}

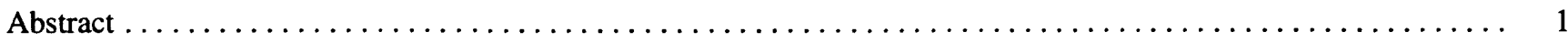

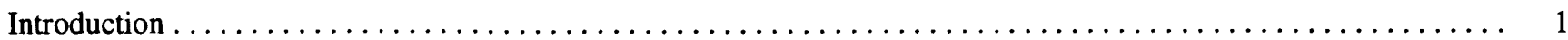

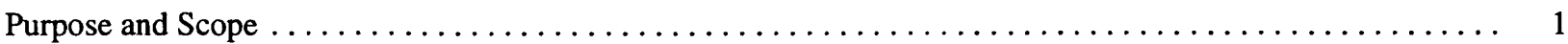

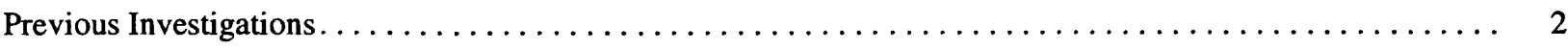

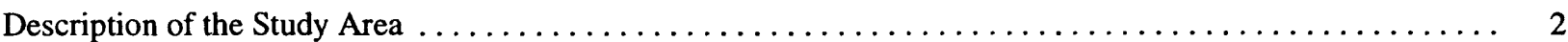

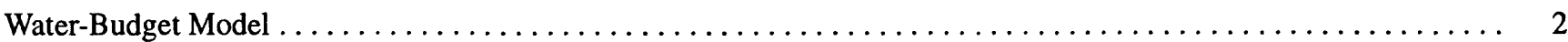

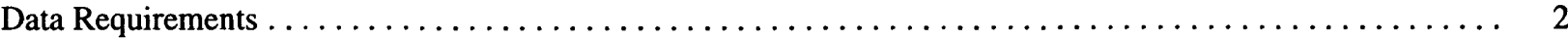

Rainfall $\ldots \ldots \ldots \ldots \ldots \ldots \ldots \ldots \ldots \ldots \ldots \ldots \ldots \ldots \ldots \ldots \ldots \ldots \ldots \ldots$

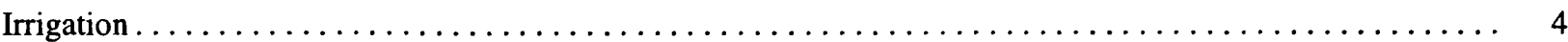

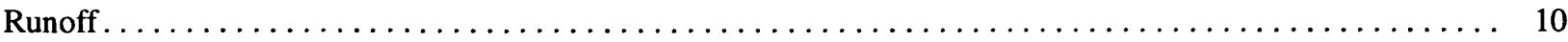

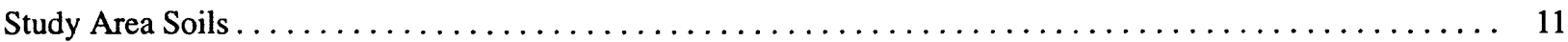

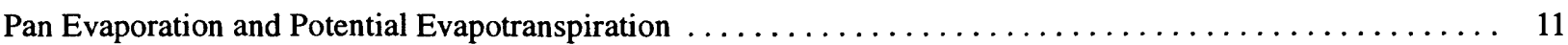

Actual Evapotranspiration and Soil-Moisture Accounting. . . . . . . . . . . . . . . . . 13

Ground-Water Recharge . . . . . . . . . . . . . . . . . . . . . . . . . . . 15

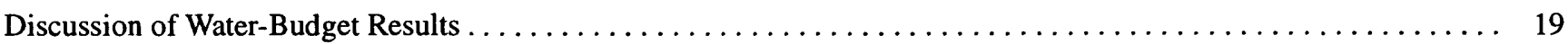

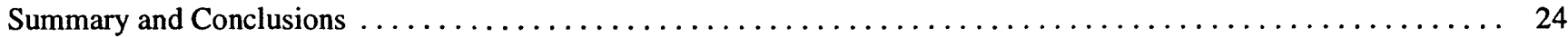

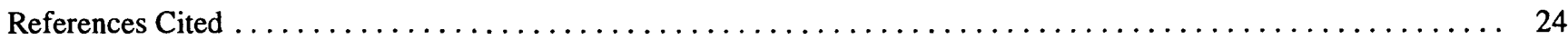

\section{Figures}

1-8. Maps showing:

1. West Maui and the Iao study area, Hawaii. . . . . . . . . . . . . . . . . . . . .

2. High-level ground-water divide, Iao area, Maui, Hawaii $\ldots \ldots \ldots \ldots \ldots$

3. Mean annual rainfall in the Iao area, Maui, Hawaii. . . . . . . . . . . . . . . . . . 6

4. March (wet season) rainfall in the Iao area, Maui, Hawaii . . . . . . . . . . . . . . . .

5. June (dry season) rainfall in the Iao area, Maui, Hawaii $\ldots \ldots \ldots \ldots \ldots$

6. Agricultural land use for three model scenarios, Iao area, Maui, Hawaii . . . . . . . . . . . . . . . 9

7. Maximum soil-moisture storage in the Iao area, Maui, Hawaii. . . . . . . . . . . . . . . 12

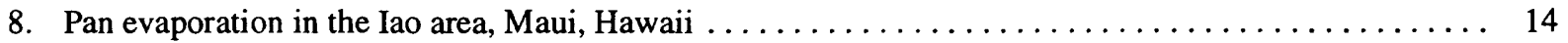

9. Diagram showing soil-moisture storage in the Iao area, Maui, Hawaii . . . . . . . . . . . . . 15

10. Map showing estimated ground-water recharge for four model scenarios, Iao area, Maui, Hawaii . . . . . . 17

Tables

1. Monthly direct runoff-rainfall ratios for the drainage area gaged at 16604500 and the high-level part of the Iao area, Maui, Hawaii. . . . . . . . . . . . . . . . . . . . . . .

2. Annual direct runoff-rainfall ratios for basal ground-water part of Iao area, Maui, and Pearl Harbor, Oahu, Hawaii. . . . . . . . . . . . . . . . . . . . . . . . . . . . . .

3. Average soil characteristics in the Iao area, Maui, Hawaii $\ldots \ldots \ldots \ldots \ldots$ 


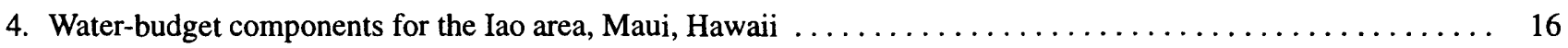

5. Water-budget components for high-IeveI ground-water area, Iao area, Maui, Hawaii $\ldots \ldots \ldots \ldots \ldots \ldots \ldots$

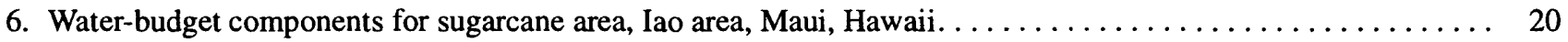

7. Water-budget components for the basal ground-water area of the Iao area, Maui, Hawaii . . . . . . . . . 21

8. Water-budget components for agricultural fields in the Iao area, Maui, Hawaii $\ldots \ldots \ldots \ldots \ldots \ldots \ldots \ldots \ldots 21$

9. Monthly water-budget ratios for four model scenarios for the Iao area, Maui, Hawaii $\ldots \ldots \ldots \ldots \ldots \ldots 22$

10. Annual water-budget ratios for four model scenarios, Iao area, Maui, Hawaii $\ldots \ldots \ldots \ldots \ldots \ldots \ldots \ldots \ldots$

11. Water-budget estimates from various investigations, Iao area, Maui, Hawaii. . . . . . . . . . . . . . 23

\section{Conversion Factors}

\begin{tabular}{rll}
\hline Multiply & By & To obtain \\
\hline foot (ft) & 0.3048 & meter \\
million gallons per day $(\mathrm{Mgal} / \mathrm{d})$ & 0.04381 & cubic meter per second \\
square mile $\left(\mathrm{mi}^{2}\right)$ & 2.590 & square kilometer \\
inch $(\mathrm{in})$. & 25.4 & millimeter \\
inch per day (in/d) & 2.54 & centimeter per day \\
inch per year (in/yr) & 2.54 & centimeter per year \\
\hline
\end{tabular}




\title{
Water Budget for the lao Area, Island of Maui, Hawaii
}

\author{
By Patricia J. Shade
}

\section{Abstract}

Ground-water recharge is estimated as the residual component of a monthly water budget calculated using soil characteristics and long-term average rainfall, streamflow, irrigation, and panevaporation data. The water-budget components of rainfall, direct runoff, evapotranspiration, and ground-water recharge are defined seasonally, through the use of monthly data, and spatially by land-use and geohydrologic areas, through the use of a geographic information system model.

The long-term average ground-water recharge for the Iao area was estimated for four scenarios using natural land-use, and using 1926-79, 198085 , and 1986-95 land-use and irrigation data. The recharge rate for natural conditions is 34 million gallons per day, which is 34 percent of rainfall. The average annual ground-water recharge rate for 1926-79 conditions is 51 million gallons per day, which is 41 percent of the sum of rainfall and irrigation. The recharge rates for $1980-85$ and 198695 conditions are 40 and 36 million gallons per day, which are 37 and 35 percent of rainfall plus irrigation, respectively.

\section{INTRODUCTION}

Ground water developed from the lao area is the most important source for the municipal supply on the island of Maui. Although there is abundant rainfall in the mountainous upland watershed, ground-water development in that area is difficult. Ground-water development is concentrated in the basalt aquifer at a few specific areas at lower altitudes closer to the coast.
Irrigated plantation agriculture has been the dominant land use overlying the basalt aquifer since Wailuku Sugar Company was formed in 1875 . Thousands of acres of sugarcane were irrigated from both surfaceand ground-water sources for more than 100 years. Currently Wailuku Agribusiness cultivates sugarcane, macadamia nut trees, and pineapple that are irrigated from surface-water sources. Ground-water recharge from the application of millions of gallons of irrigation water each day is a major component in the assessment of the ground-water resource in this area.

In an effort to meet the present and future water demand and to increase knowledge of the ground-water system in the Iao area, the Maui County Department of Water Supply entered into a cooperative agreement with the U.S. Geological Survey (USGS) to study ground-water availability in the Iao area. The project includes a water-budget calculation and analysis of the ground-water flow system.

\section{Purpose and Scope}

The purpose of this report is to describe the calculation of a mean monthly water budget for the Iao area of the island of Maui. Included in the water budget is a calculation of ground-water recharge, which is an important element in the analysis of the ground-water flow system. The monthly calculations yield a more accurate value of ground-water recharge, compared with calculations made on a mean annual basis, because the method accounts for actual evapotranspiration and water held in the soil root zone seasonally, rather than assuming a maximum, potential evapotranspiration rate. A water budget was calculated for four land-use scenarios. The monthly spatial distribution of the waterbudget components is tabulated by geohydrologic and 
land-use areas, and the ground-water recharge spatial distribution is displayed.

\section{Previous Investigations}

Several reports address various aspects of the water resources of the Iao aquifer-system area. The studies containing water-budget estimates relevant to this investigation include those by the Commission on Water Resource Management (1990); Yamanaga and Huxel (1970); and Caskey (1968).

\section{Description of the Study Area}

The study area encompasses $24.69 \mathrm{mi}^{2}$ from the crest of the West Maui Mountain, an extinct volcano (fig. 1), along the southern divide of Waihee River valley and the northern topographic divide of Waikapu Stream valley to the coast. Rainfall is abundant along the crest, which peaks at an altitude of $5,785 \mathrm{ft}$ at Puu Kukui. Iao and Waiehu Streams originate in the area of high rainfall and have carved deeply incised valleys into this extinct volcanic dome. Streamflow in the uplands is perennial, fed by ground-water discharge. Much of this stream discharge is diverted through a network of ditches and tunnels for irrigation of sugarcane, macadamia nut trees, and pineapple fields. Conservation land use dominates the uplands. Small communities and agriculture occupy the gently sloping coastal plain.

A geohydrologic subdivision of the study area was helpful in tabulating the water-budget results for use in subsequent ground-water modeling of the area. Ground water moves from the West Maui Mountain toward the ocean. Within the rift zone of this volcano, subsurface barriers consisting of low-permeability basaltic dikes impede ground-water movement and force water levels in wells to several hundred feet above mean sea level. As described by Takasaki (1978), the effect of the dike barriers is to subdivide the aquifer-system area into the high-level ground-water area, as it is commonly referred to in Hawaii, and the basal-water area. Basal water, also called the Ghyben-Herzberg lens, is a body of freshwater that floats on saltwater near sea level within the more permeable, dike-free lava flows on the flank of the volcano. This basal lens is somewhat protected from seawater encroachment by a relatively impermeable layer of sedimentary deposits, locally known as caprock.

\section{WATER-BUDGET MODEL}

Aquifers are replenished by ground-water recharge from rainfall and irrigation water that percolates through and beyond the root zone in the soil to the subsurface rock. Ground-water recharge can be estimated using a water-budget model. The method used in this study for calculating the water budget is similar to that developed by Thornthwaite (1948) and Thornthwaite and Mather (1955) and is an accounting procedure that balances moisture inputs of rainfall and irrigation water, and moisture outputs of direct runoff, evapotranspiration, and ground-water recharge. This budgeting method is a coarse representation of the continuous processes of soil-wetting by and plant interception of rainfall, runoff in streams, the return of moisture to the atmosphere by way of evapotranspiration (evaporation from soil, plant, and water surfaces and transpiration by plants), and percolation past the plant root zone to recharge ground water. The relation of the water-budget components is expressed by:

$$
G=P+I-R-E-\Delta S S,
$$

where:

$$
\begin{aligned}
G & =\text { ground-water recharge } \\
P & =\text { precipitation (rainfall) } \\
I & =\text { irrigation } \\
R & =\text { direct runoff } \\
E & =\text { evapotranspiration, and } \\
\Delta S S & =\text { change in soil-moisture storage. }
\end{aligned}
$$

In the water-budget model, direct runoff is calculated as a percentage of rainfall and thus the budgeting method solves for the remaining components of groundwater recharge, evapotranspiration and the change in soil-moisture storage. The monthly values of each water-budget component represent average long-term climatic conditions.

\section{Data Requirements}

A geographic information system (GIS) model was created to calculate the monthly water budget by linking the spatial and quantitative characteristics of the variables in equation 1 . The data requirements for the GIS water-budget model include spatial distributions of rainfall, agricultural irrigation, land-use, runoff (streamflow) and associated drainage area, pan-evaporation, and soil properties. The spatial data allow the 


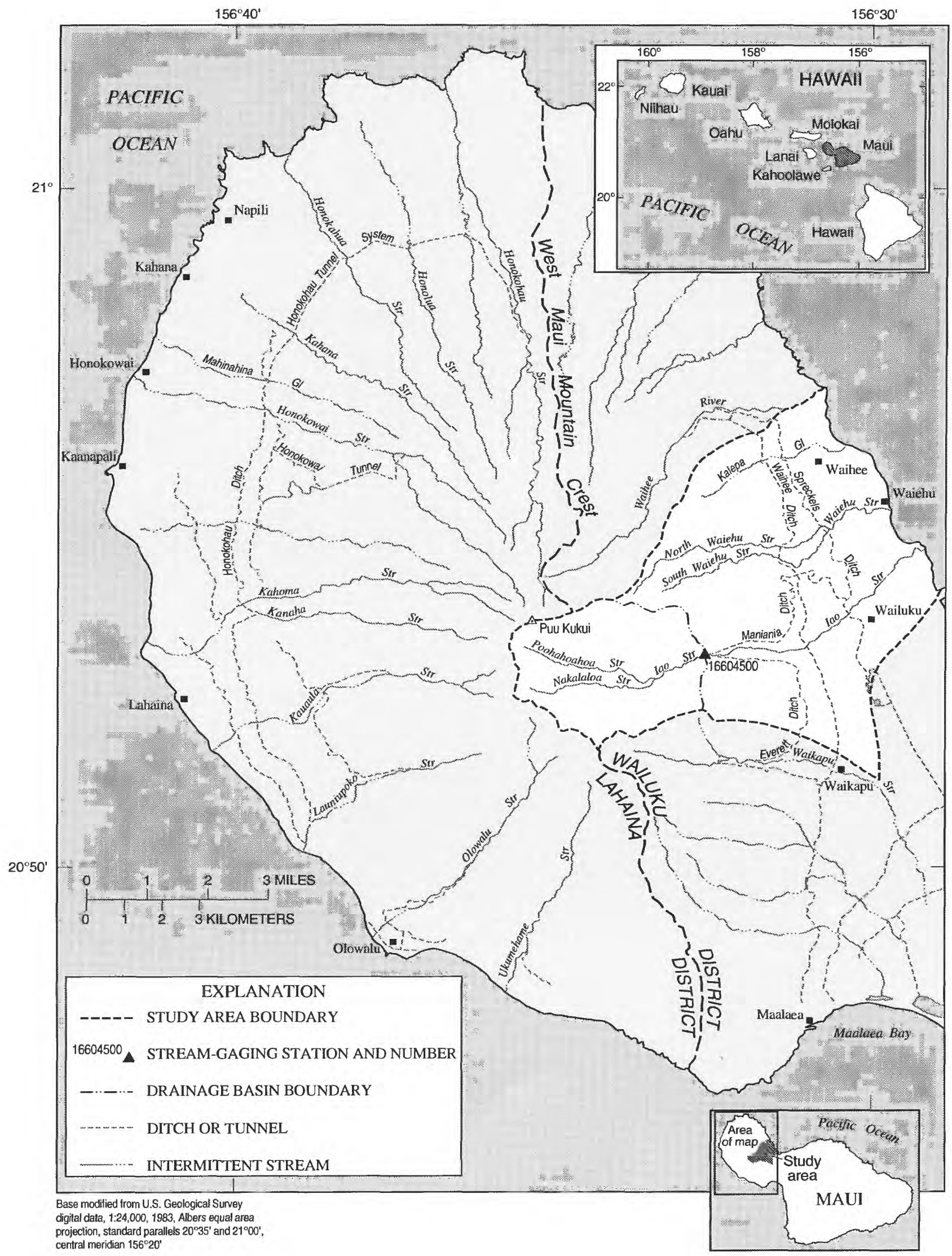

Figure 1. West Maui and the lao study area, Hawaii. 
water-budget components to be calculated and displayed by individual area or any combination of areas.

The study area was digitized from 1:24,000-scale USGS topographic maps prepared in 1983. The area was divided into two water-occurrence areas, high-level ground water and basal ground water, by the delineation of the approximate location of subsurface ground-water flow barriers (fig. 2). This subdivision will aid subsequent ground-water flow-system analysis.

\section{Rainfall}

The rainfall distribution in the study area is influenced by an orographic effect caused by the West Maui Mountain. Because the mountain is cone-shaped, orographic rainfall can be generated by winds from any direction, not only the prevailing northeast tradewinds. The orographic lifting also is enhanced by the deeply incised valleys that funnel air toward the summit (Giambelluca and others, 1986). Thus, lines showing equal annual rainfall have an elliptical shape (fig. 3) radiating from the mountain peak where the mean annual rainfall exceeds 355 in., the second highest recorded rainfall in the State (Giambelluca and others, 1986). Rainfall is abundant along the mountain crest in the study area where mean annual values range from about $155 \mathrm{in}$. at the southern end to about 315 in. near the northern end. Rainfall decreases dramatically toward the coast, where the average rainfall is about 30 in. along the shore of the study area near Waiehu.

Giambelluca and others (1986) prepared twelve maps showing lines of equal mean monthly rainfall for the island of Maui. The maps were compiled from data collected at more than 250 stations including a network of 18 base stations that had complete records for the base period from 1916 through 1983. Records from an additional 11 stations were used in their statistical analyses. In the analysis of mean annual rainfall, the most weight was given to stations with the longest record. Yet some inconsistencies among nearby stations remained. Adjustments were made on the basis of the available data and on knowledge of the rainfall-producing mechanisms. Thus, there is an element of subjectivity incorporated into these maps (Giambelluca and others, 1986). These monthly maps were digitized and constitute the rainfall data set for the GIS model. The value assigned to the area between the lines of equal rainfall is the average value of the bounding lines. Fig- ures 4 and 5 are representative of the rainfall distribution in the wet and dry seasons, respectively. In March, rainfall at Waiehu averages slightly less than $3 \mathrm{in}$. and in June rainfall averages about 0.7 in. Although the magnitude of rainfall at Puu Kukui is greater, a similar variability occurs, with about 40 in. of rainfall in March and 20 in. in June.

The spatial distribution of rainfall varies from month to month, and most significantly from winter to summer months. These data were integrated over the study area to calculate mean monthly rainfall volumes that range from a high of $146 \mathrm{Mgal} / \mathrm{d}$ in March to a low of $37 \mathrm{Mgal} / \mathrm{d}$ in June. Rainfall ranges from about 126 to $146 \mathrm{Mgal} / \mathrm{d}$ from November through April and from about 37 to $84 \mathrm{Mgal} / \mathrm{d}$ from May through October.

\section{Irrigation}

Irrigation water was distributed in the GIS model by the use of a digital land-use map of the agricultural fields digitized by the USGS from a 1:24,000-scale field map provided by Wailuku Agribusiness. Average values of applied water for various time periods were compiled from Wailuku Agribusiness data.

Substantial volumes of water are used for agricultural irrigation in the Iao area. Perennial flow in the upper reaches of Iao and Waiehu Streams, and flow from the Waihee River outside of the Iao area is diverted by a large system of ditches (fig. 2). The average diversion for all agricultural irrigation is about 55 $\mathrm{Mgal} / \mathrm{d}$ (Commission on Water Resource Management, 1990, p. D9). Ground water developed at an inclined shaft, shaft 33, was also used to irrigate fields during the period of scenario II. The distribution of large volumes of irrigation water in the Iao area has significant effects on the components of evapotranspiration and groundwater recharge in the water budget.

Four scenarios of irrigation patterns were modeled. Scenario I represents the natural land-use distribution with no agricultural irrigation. Scenario II represents the plantation agricultural field distribution and a representative value of applied water, $137 \mathrm{in} / \mathrm{yr}$, for the period from 1926 through 1979 (fig. 6). During this period only sugarcane was grown on the plantation using furrow irrigation methods. By identifying fields on the map that were in production during this time, the agricultural area for this scenario was calculated as 2,445 acres in the GIS model. The applied water for sce- 

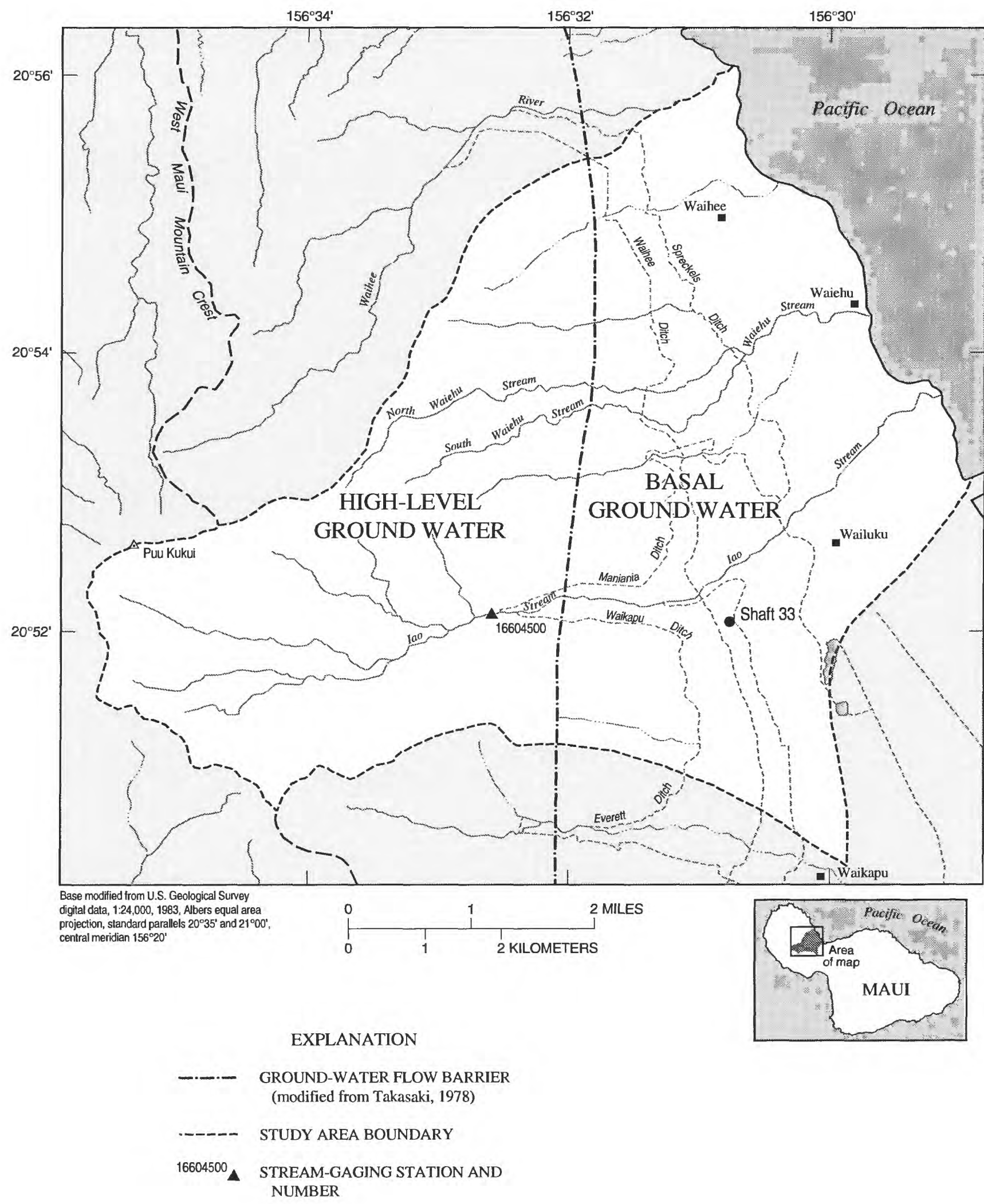

Figure 2. High-level ground-water divide, lao area, Maui, Hawaii. 


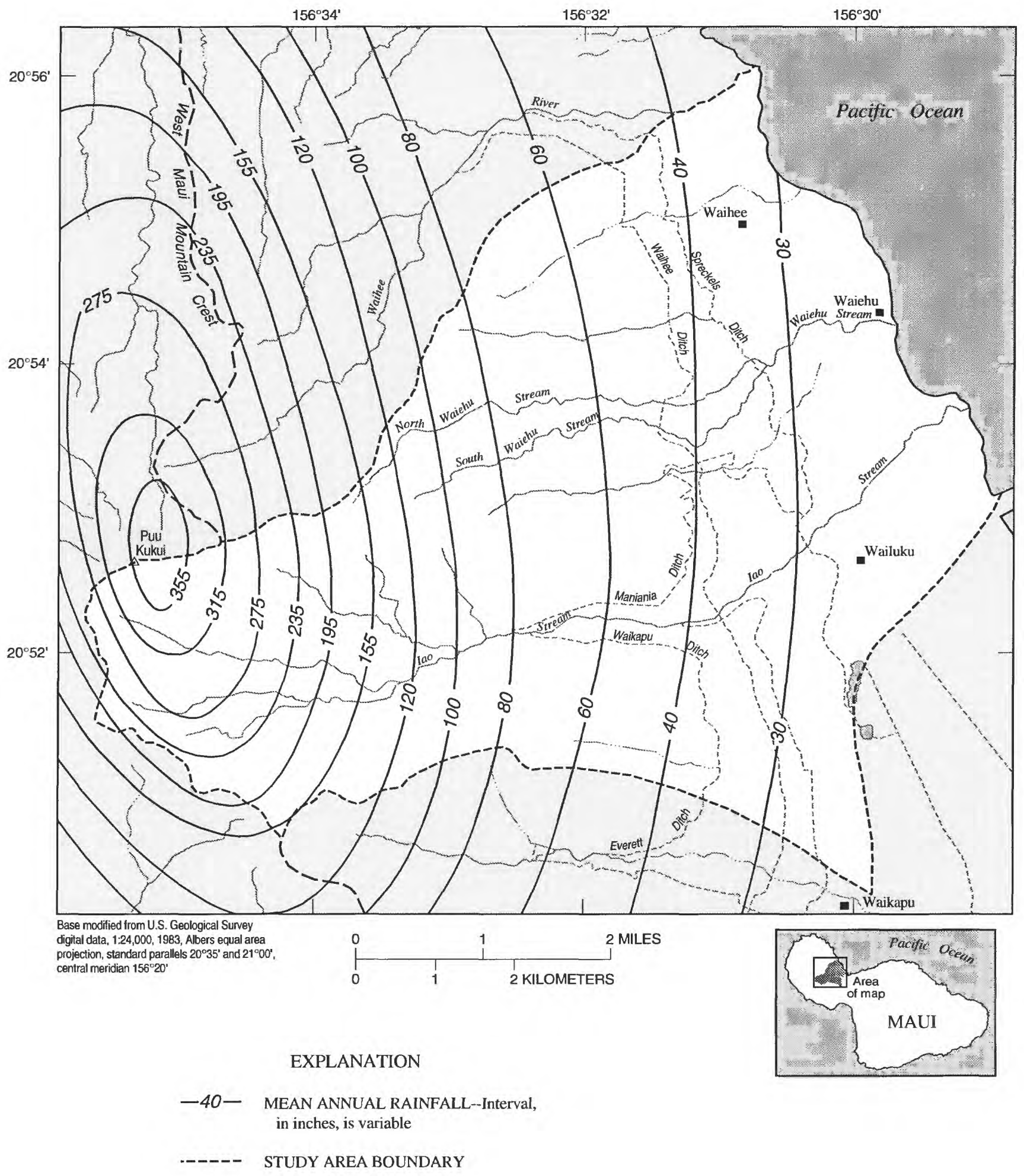

Figure 3. Mean annual rainfall in the lao area, Maui, Hawaii (modified from Giambelluca and others, 1986). 


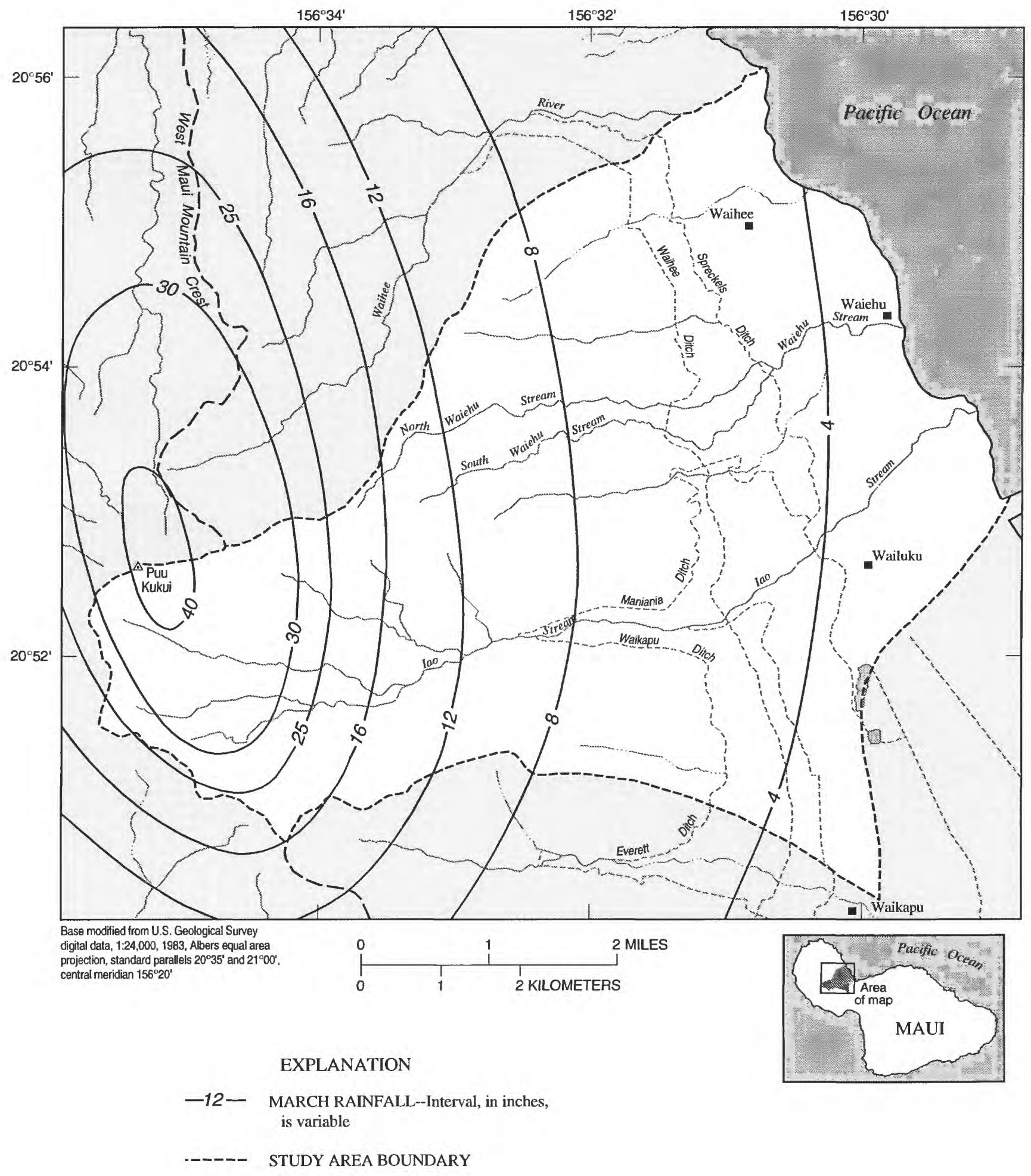

Figure 4. March (wet season) rainfall in the lao area, Maui, Hawaii (modified from Giambelluca and others, 1986). 


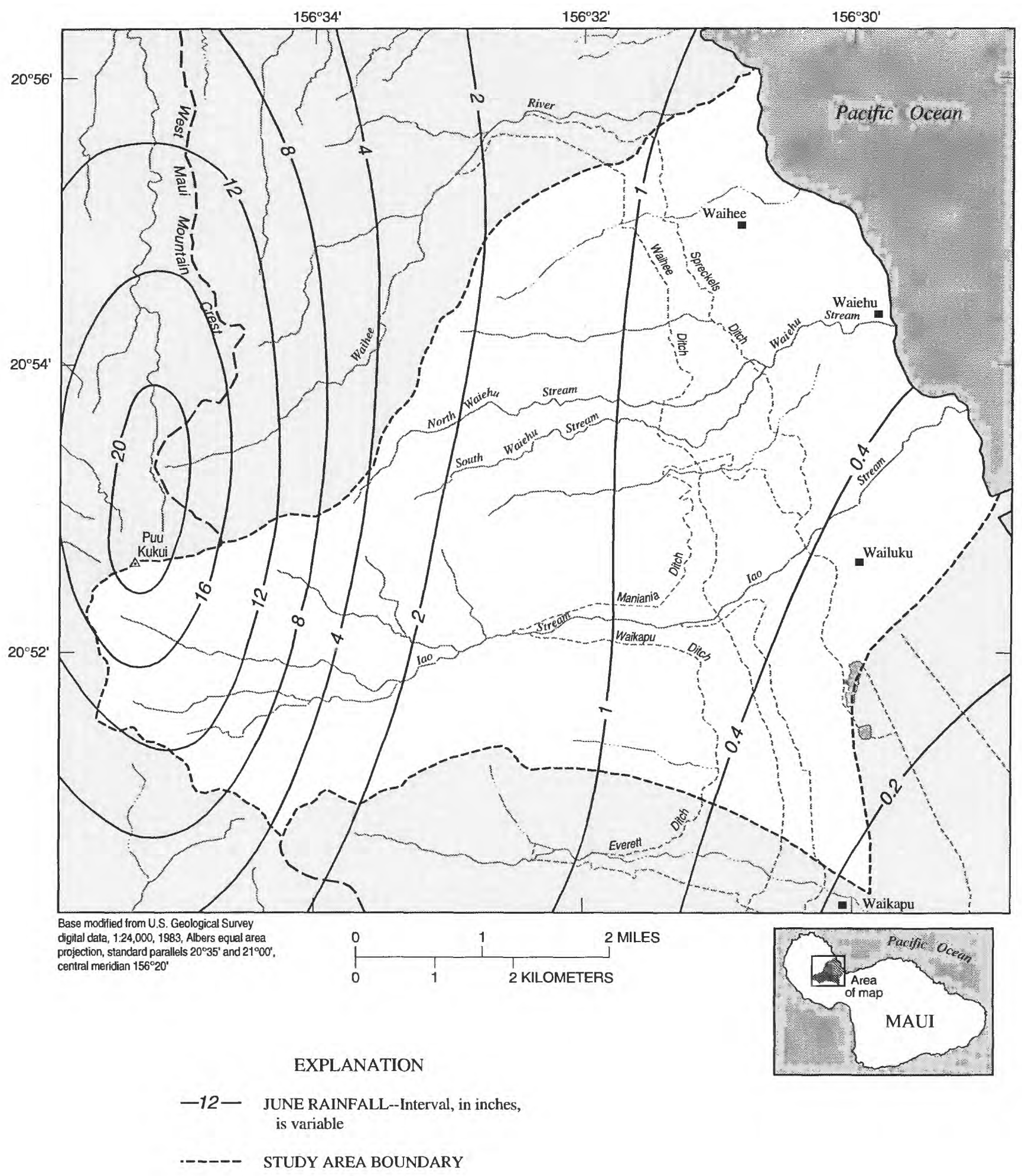

Figure 5. June (dry season) rainfall in the lao area, Maui, Hawaii (modified from Giambelluca and others, 1986). 


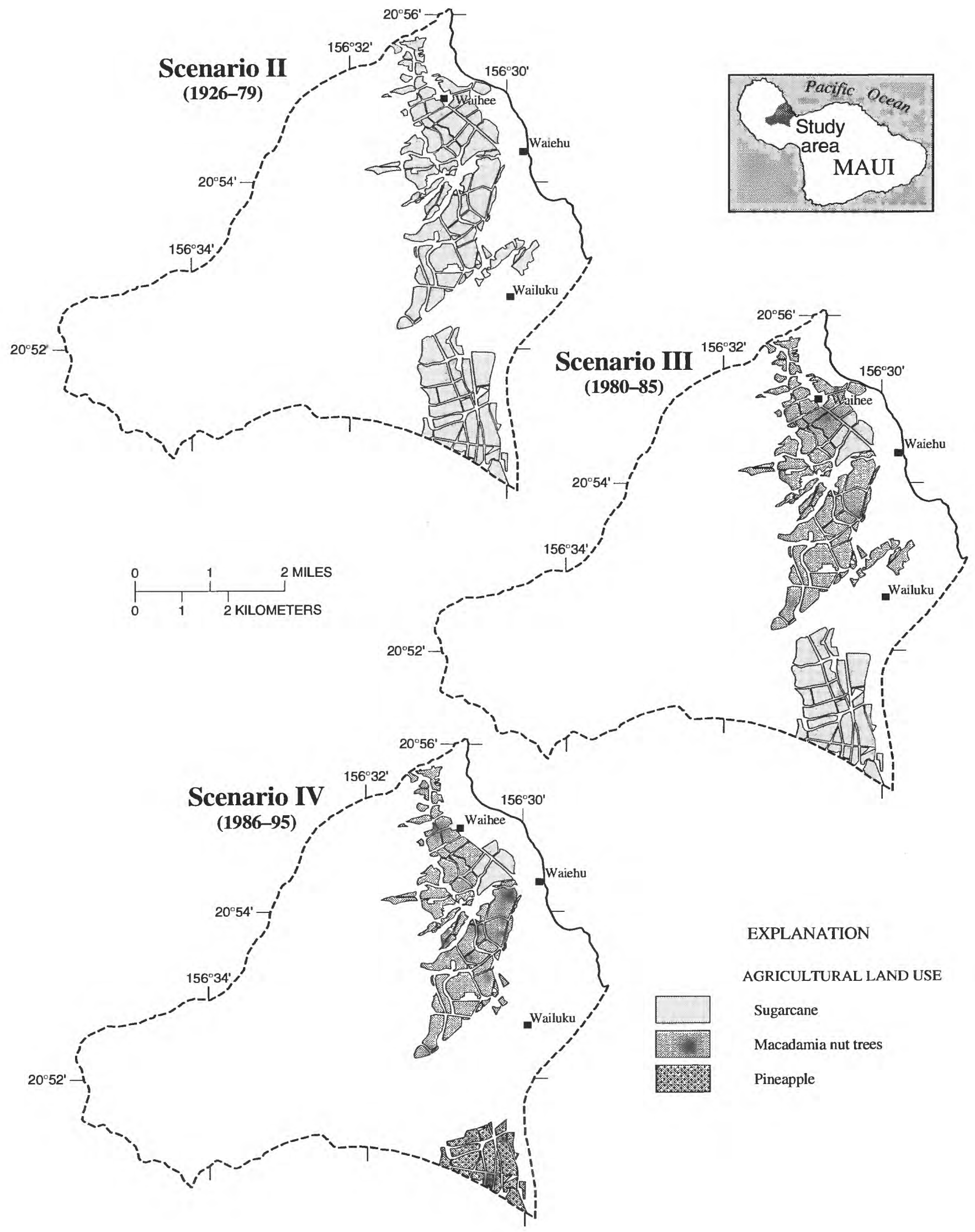

Figure 6. Agricultural land use for three model scenarios, lao area, Maui, Hawaii. 
nario II was estimated as the sum of the annual groundwater pumpage and surface-water diversions in 1979. Because data were limited, irrigation was distributed homogeneously through the months. The estimated mean irrigation during $1926-79$ is about $25 \mathrm{Mgal} / \mathrm{d}$, which distributed over this acreage equals about 137 in/yr of applied water. This rate is not unusual given the inefficient furrow-irrigation method and the peak water-use of mature sugarcane of about $124 \mathrm{in} / \mathrm{yr}$, documented by lysimeter studies in central Maui (Campbell and others, 1959).

In scenario III, 1980-85, the area of sugarcane cultivation decreased to about 940 acres in the GIS model, and about 1,505 acres were planted in macadamia nut trees (fig. 6). During this time the sugarcane irrigation method changed from furrow to drip, by which smaller volumes of water are applied directly at the base of the plants. From irrigation data available for 1985 and information from Wailuku Agribusiness (Clayton Suzuki, oral commun., 1996), about $8 \mathrm{Mgal} / \mathrm{d}$ (117 in/yr) was applied to the sugarcane area. Macadamia tree acreage was irrigated by micro-sprinklers, but with substantially less water than sugarcane, about $1 \mathrm{Mgal} / \mathrm{d}$, which equates to about $9 \mathrm{in} / \mathrm{yr}$ over the area.

In scenario IV (fig. 6), 1986-95, the area of sugarcane cultivation decreased to about 130 acres, the macadamia nut tree acreage decreased slightly to about 1,320 acres, and pineapple cultivation began on about 380 acres. Irrigation rates for sugarcane and macadamia nut trees were maintained at the scenario III rates. The irrigation rate for pineapple was about $0.7 \mathrm{Mgal} / \mathrm{d}$ (26 in/yr) (Clayton Suzuki, Wailuku Agribusiness, oral commun., 1996).

\section{Runoff}

Streamflow consists of direct runoff, the water that flows into stream channels promptly after rainfall, and base runoff, the part of streamflow that is sustained through dry weather from discharge of ground water (Langbein and Iseri, 1960). To avoid the inclusion of the ground-water component of streamflow, monthly direct runoff was calculated as the difference between mean monthly streamflow and mean monthly base runoff. Base runoff was calculated in this study from monthly flow-duration analyses as the discharge quantity that occurs at least 90 percent of the time during the chosen month. This method yields a lower estimate of base runoff than standard hydrograph separation analyses, because it decreases the volume of water ascribed to base runoff during periods of high streamflow.

The Iao Stream drainage basin above stream-gaging station 16604500 (fig. 1) was digitized from a USGS 1:24,000-scale map compiled in 1983. Mean monthly rainfall volumes for this basin were calculated by overlaying the basin area with each month's rainfall distribution in the GIS model. Monthly direct runoff was calculated from 12 years of streamflow data available from station 16604500 . The monthly direct runoffrainfall ratios (table 1) were calculated for this basin and these monthly ratios were multiplied by the mean monthly rainfall amounts within the basin and over the entire high-level ground-water area (fig. 2) to compute the monthly direct runoff values for these areas in the water budget.

For the basal ground-water area (fig. 2) there are no streamflow data available representative of the runoff generated from within these boundaries. Therefore, a second procedure was followed to calculate direct runoff/rainfall ratios on the basis of soil type and rainfall. Rainfall in this area decreases from about $65 \mathrm{in} / \mathrm{yr}$ at the highest altitudes to about 25 to $29 \mathrm{in} / \mathrm{yr}$ along the coast. Runoff/rainfall ratios were developed for this range of annual rainfall, less than $100 \mathrm{in} / \mathrm{yr}$, and three generalized soil runoff characteristics: rapid, medium, and slow.

Runoff characteristics of soils in this area are described by Foote and others (1972). Soil types have a broad runoff rating of slow, medium, or rapid on the basis of texture, permeability, and slope. From results of a water balance computed for the Pearl Harbor area of Oahu (Giambelluca, 1983), comparable areas on Oahu were chosen with similar mean annual rainfall, land use, and soil properties as those of the basal ground-water

Table 1. Monthly direct runoff-rainfall ratios for the drainage area gaged at 16604500 and the high-level part of the lao area, Maui, Hawaii

[Values in percent]

\begin{tabular}{cccccccccccc}
\hline Jan. & Feb. & Mar. & April & May & June & July & Aug. & Sept. & Oct. & Nov. & Dec. \\
\hline 53 & 43 & 54 & 70 & 57 & 90 & 67 & 45 & 50 & 67 & 42 & 53 \\
\hline
\end{tabular}


part of the Iao area. The Oahu data provided average annual runoff-rainfall ratios for each soil runoff rating (table 2). Within the basal area, for each soil type, the ratios were multiplied by the sum of the monthly rainfall to calculate annual runoff values. These annual runoff values were multiplied by monthly rainfall/annual rainfall ratios to calculate monthly direct runoff values.

Table 2. Annual direct runoff-rainfall ratios for basal groundwater part of lao area, Maui, and Pearl Harbor, Oahu, Hawaii [Values in percent; <, less than; in/yr, inches per year]

Annual direct runoff / annual rainfall ratio (in percent)

\begin{tabular}{cc} 
Soil Runoff & Rain $<100 \mathrm{in} / \mathrm{yr}$ \\
\hline Rapid and medium rapid & 13 \\
Medium & 12 \\
Slow & 12 \\
\hline
\end{tabular}

\section{Study Area Soils}

The soils have been mapped, digitized, and their characteristics tabulated by the Natural Resources Conservation Service (Foote and others, 1972) (table 3). Values of permeability, available water capacity (a measure of the quantity of water held by the soil available to plants between field capacity and wilting point), root depth, and general runoff characteristics presented by Foote and others (1972) were entered into data tables associated with the mapped soil types.

Data that were not available from Foote and others (1972) were provided by the Natural Resources Conser- vation Service (Saku Nakamura, oral commun., 1995). The available-water capacity for each soil group in table 3 is the average of the range reported by Foote and others (1972). The root depth was assumed to be at the depth where the soil-profile description changed from "abundant roots" or "common roots" to "few roots" or "no roots." The maximum soil-moisture storage $\left(\mathrm{SS}_{\max }\right)$ is the product of the root depth and the available water capacity for the soil type (table 3 ). A digital map (fig. 7) of the distribution of maximum soil-moisture storage values was created for use in the GIS model. The $\mathrm{SS}_{\max }$ value is important in the water-budget model because it is the maximum limit for evapotranspiration and is also the limit above which groundwater recharge occurs.

\section{Pan Evaporation and Potential Evapotranspiration}

Pan evaporation data from class-A evaporating pans provide an estimate of the potential (maximum) evapotranspiration. Potential evapotranspiration $(\mathrm{PE})$ is an estimate of the amount of water that could be evapotranspired from a given area, assuming a continuous water supply. Thus, potential evapotranspiration, although influenced by other factors, is primarily a function of solar radiation energy (Chang, 1968, p. 131 and Mather, 1978 , p. 8). Therefore in dry, sunny areas, actual evapotranspiration can rarely occur at the estimated potential rate without irrigation, because there is a lack of water to satisfy the maximum demand

Table 3. Average soil characteristics in the lao area, Maui, Hawaii [Data from Foote and others, 1972; Saku Nakamura, Natural Resources Conservation Service, oral commun., 1995]

\begin{tabular}{|c|c|c|c|c|}
\hline Soil series & $\begin{array}{c}\text { Permeability } \\
\text { (inches per hour) }\end{array}$ & $\begin{array}{l}\text { Available-water capacity } \\
\text { (inch per inch of soil) }\end{array}$ & $\begin{array}{l}\text { Root depth } \\
\text { (inches) }\end{array}$ & $\begin{array}{l}\text { Maximum soil- } \\
\text { moisture storage } \\
\text { (inches) }\end{array}$ \\
\hline Fill land $\ldots \ldots \ldots \ldots \ldots \ldots \ldots$ & $0.6-2.0$ & 0.15 & 30 & 4.50 \\
\hline Halawa . . . . . . . . . . . . & $2.0-6.3$ & 0.135 & 44 & 5.72 \\
\hline Iao. . . . . . . . & $0.2-0.6$ & 0.14 & 25 & 3.50 \\
\hline Jaucas $\ldots \ldots \ldots \ldots \ldots \ldots \ldots$ & $6.3-20$ & 0.045 & 13 & 0.59 \\
\hline Naiwa ..................... & $2.0-6.3$ & 0.10 & 52 & 5.20 \\
\hline Pulehu $\ldots \ldots \ldots \ldots \ldots \ldots \ldots$ & $0.6-2.0$ & 0.135 & 33 & 4.46 \\
\hline Puuone $\ldots \ldots \ldots \ldots \ldots \ldots \ldots$ & $6.3-20$ & 0.07 & 20 & 1.40 \\
\hline Rough broken land............. & $0.6-2.0$ & 0.15 & 30 & 4.50 \\
\hline Rough mountainous land ......... & $2.0-6.0$ & 0.135 & 25 & 3.38 \\
\hline Stony alluvial land $\ldots \ldots \ldots \ldots \ldots$ & $2.0-6.0$ & 0.06 & 50 & 3.00 \\
\hline Wailuku . . . . . . . . . . . & $0.6-2.0$ & 0.14 & 12 & 1.68 \\
\hline
\end{tabular}




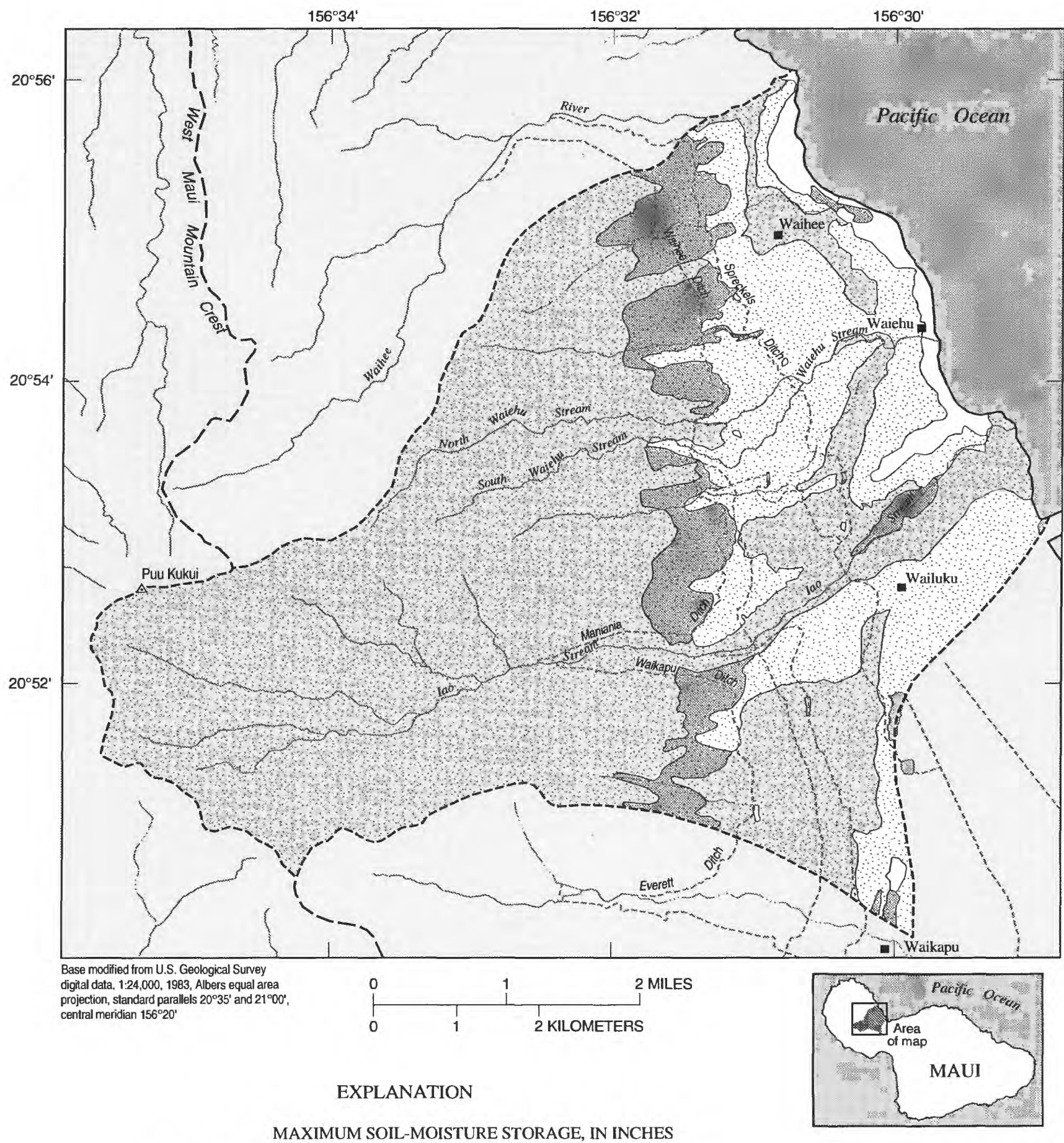

MAXIMUM SOIL-MOISTURE STORAGE, IN INCHES

Less than or equal to 1

Greater than 1 and less than or equal to 2

Greater than 2 and less than or equal to 4

Greater than 4

STUDY AREA BOUNDARY

Figure 7. Maximum soil-moisture storage in the lao area, Maui, Hawaii. 
described by the potential evapotranspiration value. For this study, pan evaporation is assumed to equal potential evapotranspiration on the basis of the results of lysimeter studies in sugarcane fields (Chang, 1968; Campbell and others, 1959) where the average ratio between potential evapotranspiration and pan evaporation was about 1.0 .

The map of mean annual pan evaporation for Maui (Ekern and Chang, 1985) is shown in figure 8 and was digitized for the GIS water-budget model of the study area. The average of the values of the bounding lines of equal pan evaporation was assigned to the area between the two lines. Only a few pan evaporation stations have been established by sugarcane growers in the study area (fig. 8). Other pan evaporation stations outside of the study area aid in estimating the location of lines of equal pan evaporation. Data were not available for the area towards the mountain crest above the 70-in. line.

Annual values for this area were estimated on the basis of a rainfall-pan evaporation relation (eq. 2) established using data from the island of Hawaii (Giambelluca and others, 1983; and Ekern and Chang, 1985) for an area with similar windward exposure to the prevailing tradewind flow and similar gradients of increasing rainfall, cloud cover, and lower temperatures with increasing altitude:

\section{Annual Pan Evaporation $=295.96 \times$ Annual Rain $^{-0.44}$}

The annual pan evaporation was distributed monthly on the basis of a set of monthly factors that describe the relation between the monthly and annual rainfall values:

$$
\operatorname{Pan}_{m}=\frac{\text { annual pan }\left(x / \text { Rain }_{m}\right)}{y},
$$

where $x=$ annual rain $/ 12$ and

$$
y=\sum_{m=1}^{12} \frac{x}{\text { Rain }_{m}} .
$$

The monthly pan evaporation values are inversely related to rainfall, decreasing in the wet and cloudy winter months and increasing in the dry and sunny summer months.

\section{Actual Evapotranspiration and Soil-Moisture Accounting}

Actual evapotranspiration is the quantity of water evaporated from water, plant and soil surfaces and transpired by plants. Actual evapotranspiration data from direct field measurements do not exist for the Iao area; however, it is possible to estimate actual evapotranspiration from pan evaporation and soil data.

The potential evapotranspiration (pan evaporation) demand in a particular month can not always be met by the amount of water in soil storage. In such situations actual evapotranspiration will be less than the potential evapotranspiration. Because of the sequence of calculations in the water-budget model, actual evapotranspiration volumes cannot be greater than the value of maximum soil-moisture storage. Thus, actual evapotranspiration can only equal the potential value where the maximum soil-moisture storage $\left(\mathrm{SS}_{\max }\right.$ ) value is greater than or equal to potential evapotranspiration.

Because the $\mathrm{SS}_{\max }$ value limits evapotranspiration a modification was made to the GIS model in irrigated areas only. To more accurately simulate the evapotranspiration demand of the various crops and the continuous soil wetting from irrigation, $\mathrm{SS}_{\max }$ was set equal to the monthly pan evaporation value, if the calculated $\mathrm{SS}_{\max }$ value was less than pan evaporation. This change in the model creates the ability for evapotranspiration to occur at the maximum (pan) rate if water is available.

The amount of water held in the soil changes from month to month calculated by an accounting procedure. The water-budget model is initialized by beginning the month of January with three soil-moisture storage values: $\mathrm{SS}_{\max }$, half of $\mathrm{SS}_{\max }$, and zero. The resulting soilmoisture storage values at the end of December were identical for these three model runs. Thus the December values were input for the initial soil-moisture storage in January for the final water-budget calculation. In unirrigated areas, January runoff is subtracted from the sum of the initial January soil-moisture storage plus January rainfall. The remainder is added to soil-moisture storage, and if this quantity exceeds $\mathrm{SS}_{\max }$, the excess recharges groundwater. Evapotranspiration is then subtracted from soil-moisture storage at either the potential (maximum) evapotranspiration rate or at some lesser rate depending on the quantity of water in soilmoisture storage available to meet the demand. Any water remaining in soil-moisture storage is carried over 


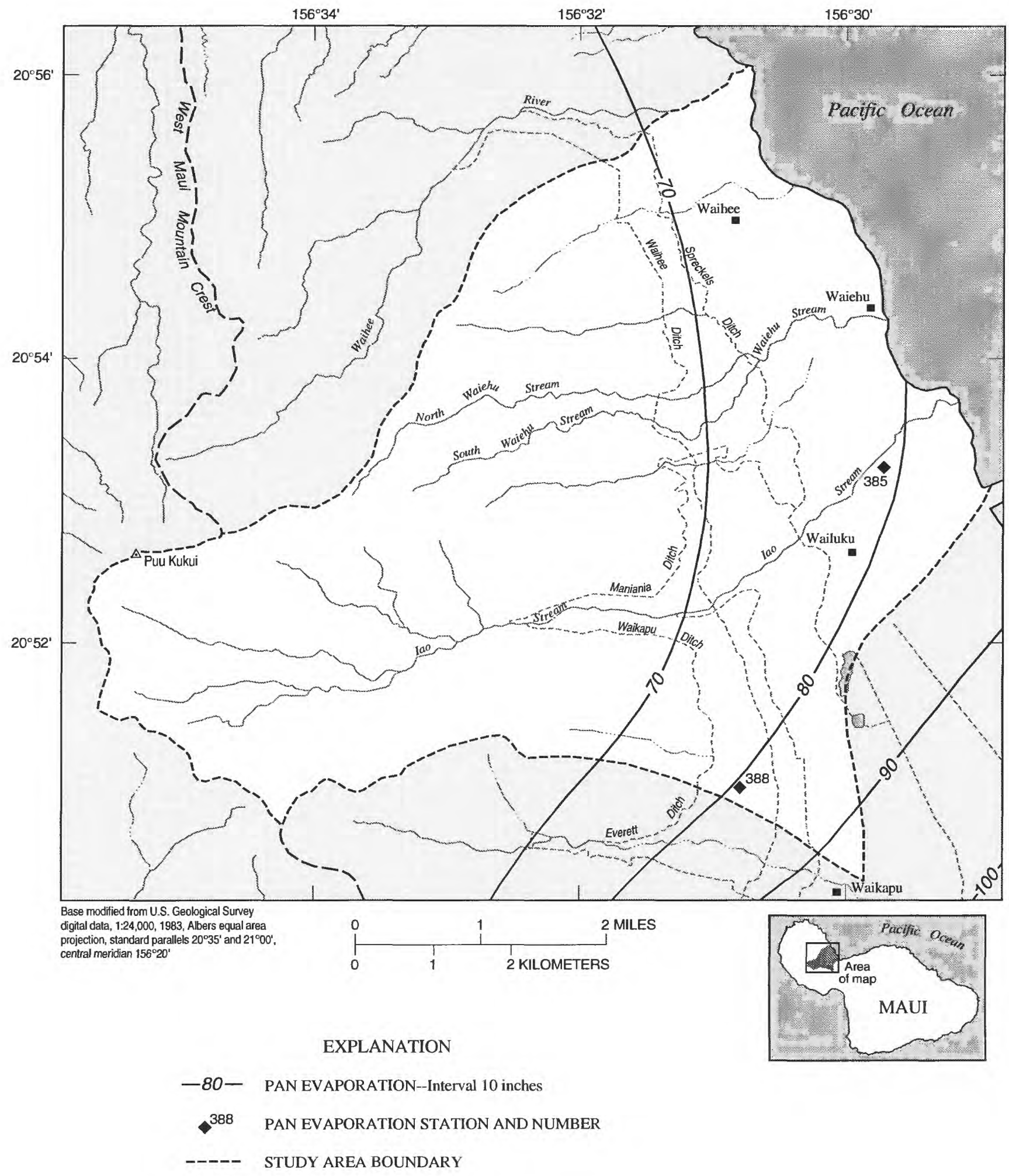

Figure 8. Pan evaporation in the lao area, Maui, Hawaii (modified from Ekern and Chang, 1985). 
to the next month. This bookkeeping procedure is shown in the following equations and figure 9.

$$
X_{1}=S S_{m}+P_{m}-R_{m},
$$

where:

$\mathrm{SS}_{\mathrm{m}}=$ beginning soil-moisture storage for the month,

$\mathrm{P}_{\mathrm{m}}=$ rainfall for the month,

$\mathrm{R}_{\mathrm{m}}=$ runoff for the month, and

$\mathrm{X}_{1}=$ first interim soil-moisture storage.

$$
\begin{array}{lrr}
\text { If } X_{1}>S S_{\max }, \quad \text { OR } & \begin{aligned}
\text { If } X_{1} \leq S S_{\max }, \quad \text { (5) } \\
\text { then } \mathrm{G}=\mathrm{X}_{1}-\mathrm{SS}_{\max }
\end{aligned} \\
\text { and } \mathrm{X}_{2}=\mathrm{SS}_{\max } & & \text { then } \mathrm{G}=0 \text { and } \mathrm{X}_{2}=\mathrm{X}_{1} .
\end{array}
$$

where:

$$
\begin{aligned}
& \mathrm{SS}_{\max }=\text { maximum soil-moisture storage, } \\
& G=\text { ground-water recharge for the month, and } \\
& \mathrm{X}_{2}=\text { second interim soil-moisture storage in the } \\
& \text { month. }
\end{aligned}
$$

$$
\begin{aligned}
& \text { If } \mathrm{X}_{2} \geq \mathrm{PE}_{\mathrm{m}}, \quad \text { OR If } \mathrm{X}_{2}<\mathrm{PE}_{\mathrm{m}} \text {, } \\
& \text { then } \mathrm{ET}=\mathrm{PE} \quad \text { then } \mathrm{ET}=\mathrm{X}_{2} \\
& \text { and } X_{\text {end }}=X_{2}-P E \text {. and } X_{\text {end }}=0 \text {. }
\end{aligned}
$$

where:

$\mathrm{PE}=$ potential (maximum) evapotranspiration for the month, and

$\mathrm{ET}=$ evapotranspiration for the month, $\mathrm{X}_{\mathrm{end}}=$ soil-moisture storage at the end of the month which becomes the beginning soilmoisture storage for the next month.

\section{Ground-Water Recharge}

In the high-level and part of the basal water areas, there was no irrigation, and thus, the mean annual distribution of ground-water recharge is identical for all four scenarios. For natural conditions scenario I (fig. 10 ), there was no irrigation and the mean ground-water recharge was $34 \mathrm{Mgal} / \mathrm{d}$ (table 4). The recharge distribution in the high-level ground water area is similar to the rainfall distribution (fig. 3 ) with the highest values occurring near Puu Kukui. Higher maximum soil-moisture storage values (fig. 7) result in a decrease in ground-water recharge because more water is available

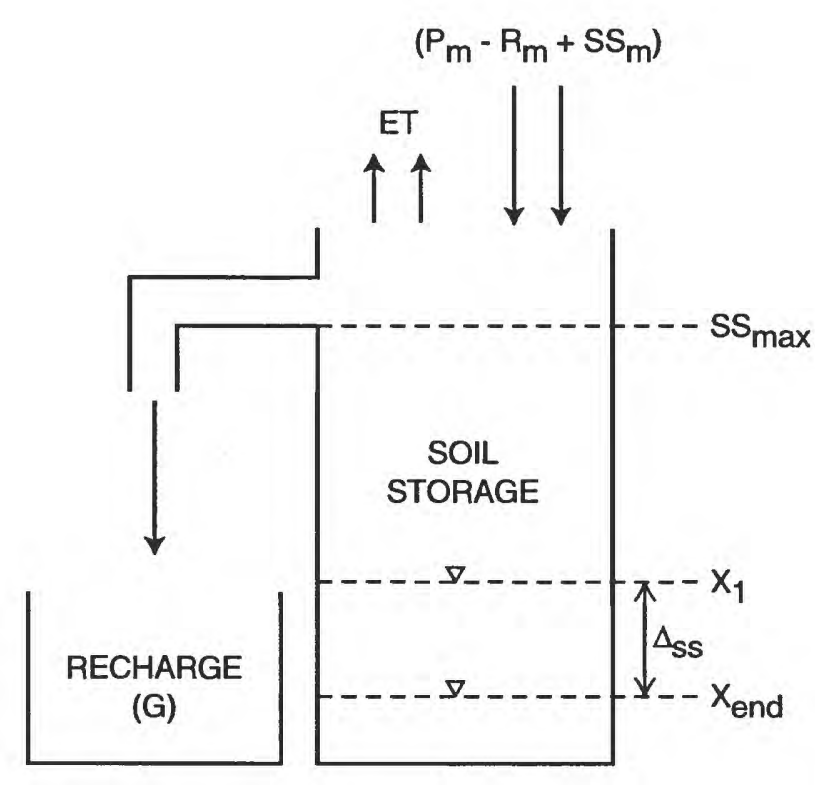

Figure 9. Diagram showing soil-moisture storage.

for evapotranspiration. This relation is apparent in areas north and south of Wailuku and near Waihee where maximum soil-moisture storage is greater than 2 and less than or equal to 4 inches (fig. 7) and recharge is less than $10 \mathrm{in} / \mathrm{yr}$ (fig. 10).

During 1926-79 (scenario II, table 4 and fig. 10), the estimated irrigation was $25 \mathrm{Mgal} / \mathrm{d}$ and the mean recharge was $51 \mathrm{Mgal} / \mathrm{d}$. Because of sugarcane cultivation and irrigation by a relatively inefficient method, recharge increased $17 \mathrm{Mgal} / \mathrm{d}$ compared with natural conditions. Recharge increased substantially in the agricultural fields compared with natural conditions; at some locations near Waihee and southwest of Wailuku, recharge increased from less than $10 \mathrm{in} / \mathrm{yr}$ in scenario I to greater than $100 \mathrm{in} / \mathrm{yr}$. In the high-level ground water area there was no change in ground-water recharge between scenarios I and II because there was no irrigation in this area.

From 1980 to 1985 (scenario III, table 4 and fig. 10) effects of irrigation on the distribution of groundwater recharge were distinct compared with scenarios I and II. The average estimated irrigation decreased from $25 \mathrm{Mgal} / \mathrm{d}$ in scenario II to a total of $9 \mathrm{Mgal} / \mathrm{d}$, of which $8 \mathrm{Mgal} / \mathrm{d}$ (117 in/yr) was for sugarcane and $1 \mathrm{Mgal} / \mathrm{d}$ (9 in/yr) was for macadamia nut trees. The decrease in the mean ground-water recharge from $51 \mathrm{Mgal} / \mathrm{d}$ in scenario II to $40 \mathrm{Mgal} / \mathrm{d}$, is directly related to the decrease 
in irrigation due to the replacement of several hundred acres of sugarcane with lower water-use macadamia nut trees (fig. 6), and the conversion of furrow irrigation to the more efficient drip and micro-sprinkler irrigation systems. In some of the sugarcane fields in the southern part of the study area, ground-water recharge decreased from greater than $100 \mathrm{in} / \mathrm{yr}$ in scenario II to between 50 and $100 \mathrm{in} / \mathrm{yr}$ in scenario III. In much of the northeastern macadamia-nut field area, recharge decreased from greater than $100 \mathrm{in} / \mathrm{yr}$ in scenario II to less than $25 \mathrm{in} / \mathrm{yr}$.

The mean recharge for the Iao area for 1986-95 (scenario IV) conditions is $36 \mathrm{Mgal} / \mathrm{d}$ (table 4). Groundwater recharge ranges from about $4 \mathrm{in} / \mathrm{yr}$ at some locations along the southern coast to about $118 \mathrm{in} / \mathrm{yr}$ at the West Maui Mountain crest (fig. 10). Irrigation was about $3 \mathrm{Mgal} / \mathrm{d}$ or $117 \mathrm{in} / \mathrm{yr}$ for sugarcane, $9 \mathrm{in} / \mathrm{yr}$ for macadamia nut trees, and about $26 \mathrm{in} / \mathrm{yr}$ for pineapple. The distinct effect of irrigation is apparent where irrigated areas have recharge as much as six times greater than that of adjoining areas. The decrease in recharge from scenario III is directly related to the decrease in irrigated acreage in the southern part of the study area and the change from sugarcane to pineapple cultivation (fig. 6).
Recharge during the winter months is considerably greater than during the summer months (table 4). Considering all scenarios together, from November through April, recharge ranges from a low of $48 \mathrm{Mgal} / \mathrm{d}$ in April of scenario I (no irrigation) to a high of $91 \mathrm{Mgal} / \mathrm{d}$ in February of scenario II (maximum irrigation). During the summer months, from May through October, recharge ranges from a low of less than $1 \mathrm{Mgal} / \mathrm{d}$ in June for all scenarios to a high of $36 \mathrm{Mgal} / \mathrm{d}$ in May of scenario II, a reflection of the maximum irrigation volumes during this scenario. The low recharge values in June are directly influenced by the distinct low rainfall values for this month.

In the high-level ground-water area there is no difference in the water-budget component values for the four scenarios (table 5) because there was no irrigation. The seasonal distribution of ground-water recharge in this area is similar to the seasonal distribution of rainfall. During the summer months recharge ranges from less than $1 \mathrm{Mgal} / \mathrm{d}$ in June to $23 \mathrm{Mgal} / \mathrm{d}$ in May. Ground-water recharge increases substantially during the winter months from a low of $31 \mathrm{Mgal} / \mathrm{d}$ in December to a high of $43 \mathrm{Mgal} / \mathrm{d}$ in February with a mean of

Table 4. Water-budget components for the lao area, Maui, Hawaii

[Scenario I is natural conditions, scenario II is 1926-79, scenario III is 1980-85, scenario IV is 1986-95. All values are in million gallons per day. The sum of rainfall plus irrigation minus direct runoff, actual evapotranspiration, and recharge may not equal zero because of rounding. The mean is calculated as the sum of monthly values divided by 12]

\begin{tabular}{|c|c|c|c|c|c|c|c|c|c|c|c|c|c|c|}
\hline $\begin{array}{l}\text { Water-budget } \\
\text { component }\end{array}$ & Scenario & Jan. & Feb. & Mar. & Apr. & May & June & July & Aug. & Sept. & Oct. & Nov. & Dec. & Mean \\
\hline Rainfall & I,II,III,IV & 137 & 132 & 146 & 134 & 84 & 37 & 68 & 74 & 60 & 79 & 130 & 126 & 100 \\
\hline \multirow[t]{4}{*}{ Irrigation } & I & 0 & 0 & 0 & 0 & 0 & 0 & 0 & 0 & 0 & 0 & 0 & 0 & 0 \\
\hline & II & 24 & 27 & 24 & 25 & 24 & 25 & 24 & 24 & 25 & 24 & 25 & 24 & 25 \\
\hline & III & 9 & 9 & 9 & 9 & 9 & 9 & 9 & 9 & 9 & 9 & 9 & 9 & 9 \\
\hline & IV & 3 & 3 & 3 & 3 & 3 & 3 & 3 & 3 & 3 & 3 & 3 & 3 & 3 \\
\hline Direct runoff & I,II,III,IV & 48 & 42 & 61 & 61 & 39 & 26 & 37 & 30 & 25 & 36 & 44 & 45 & 41 \\
\hline Pan evaporation & I,II,III,IV & 24 & 31 & 27 & 31 & 67 & 196 & 97 & 89 & 105 & 49 & 33 & 26 & 65 \\
\hline \multirow{4}{*}{$\begin{array}{l}\text { Actual evapo- } \\
\text { transpiration }\end{array}$} & I & 23 & 28 & 24 & 26 & 32 & 16 & 22 & 23 & 23 & 31 & 27 & 25 & 25 \\
\hline & II & 23 & 29 & 24 & 27 & 44 & 42 & 42 & 40 & 42 & 36 & 29 & 25 & 34 \\
\hline & III & 23 & 29 & 24 & 27 & 37 & 26 & 31 & 30 & 32 & 34 & 28 & 25 & 29 \\
\hline & IV & 23 & 29 & 24 & 27 & 34 & 19 & 24 & 25 & 25 & 33 & 28 & 25 & 26 \\
\hline \multirow[t]{4}{*}{ Recharge } & I & 64 & 65 & 59 & 48 & 24 & 0.08 & 7 & 21 & 14 & 10 & 49 & 54 & 34 \\
\hline & II & 88 & 91 & 83 & 71 & 36 & 0.09 & 11 & 28 & 20 & 29 & 71 & 79 & 51 \\
\hline & III & 73 & 74 & 68 & 56 & 28 & 0.08 & 7 & 23 & 14 & 15 & 56 & 63 & 40 \\
\hline & IV & 66 & 67 & 61 & 49 & 25 & 0.15 & 7 & 21 & 14 & 10 & 50 & 57 & 36 \\
\hline
\end{tabular}




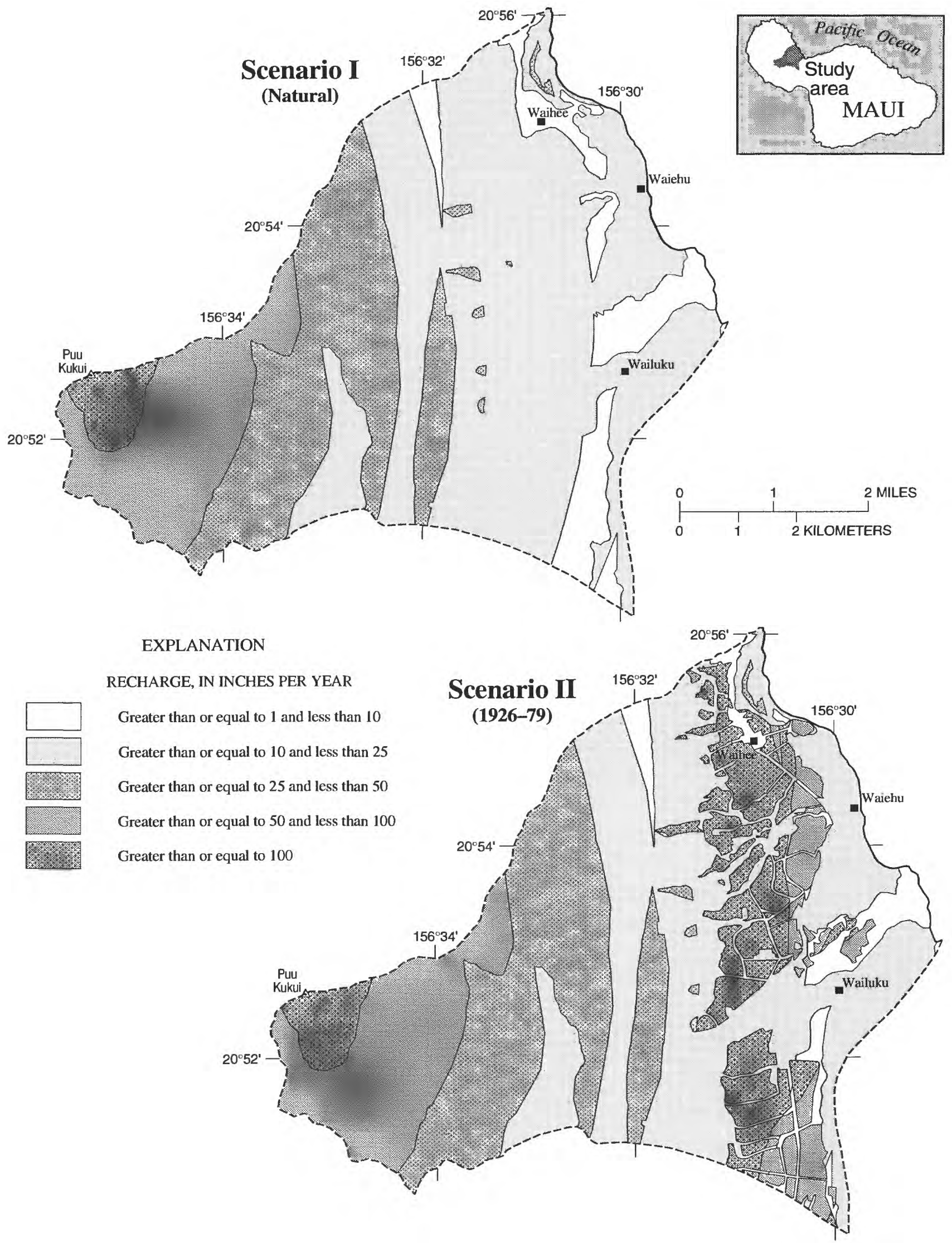

Figure 10. Estimated ground-water recharge for four model scenarios, lao area, Maui, Hawaii. 


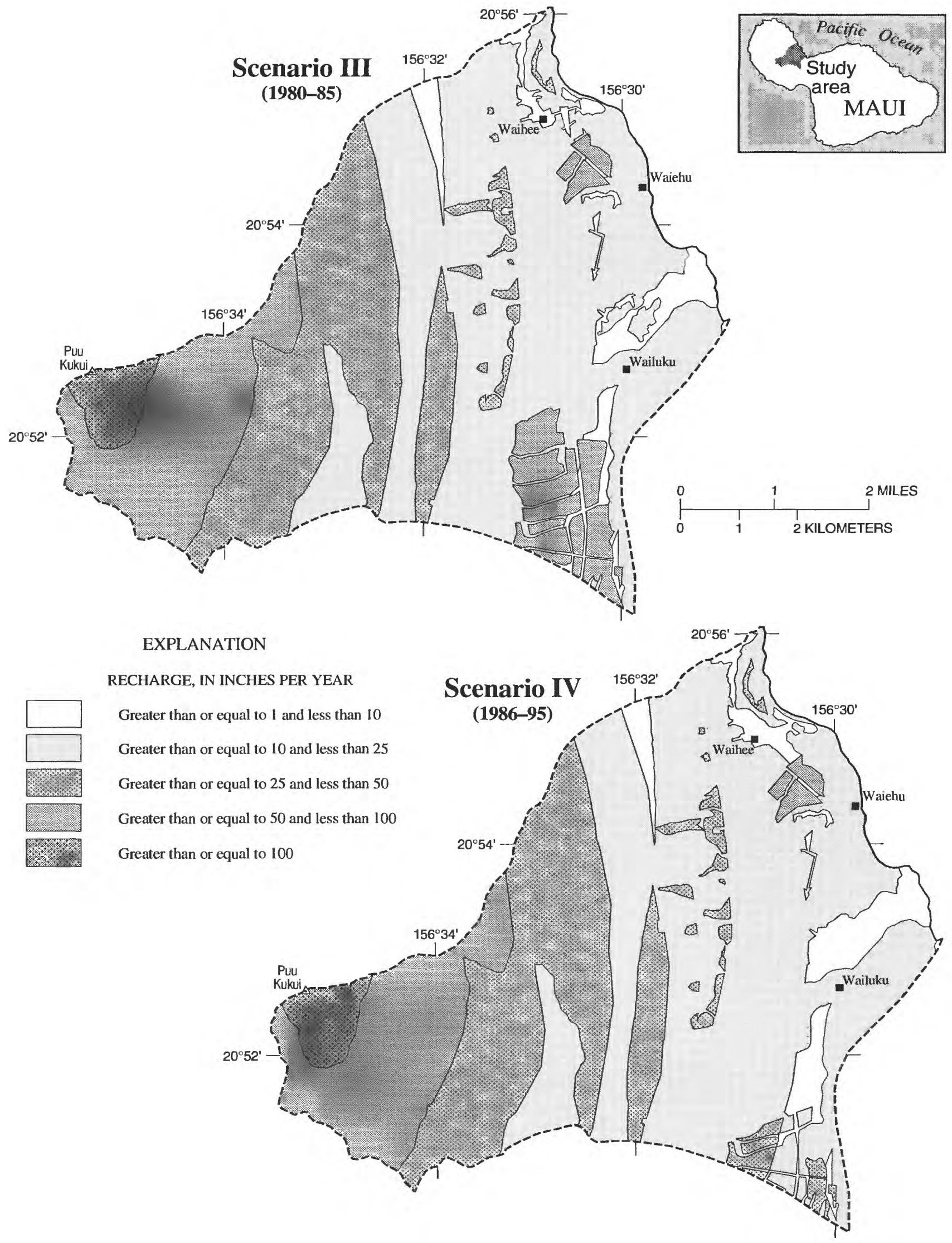

Figure 10. Estimated ground-water recharge for four model scenarios, lao area, Maui, Hawaii--Continued. 
$24 \mathrm{Mgal} / \mathrm{d}$. As a consequence of persistent cloud cover in this area, the mean evapotranspiration is only 17 percent of rainfall and does not vary significantly through the months. The ratio of actual evapotranspiration to estimated pan evaporation is 100 percent during the wet winter months and averages about 65 percent annually, a reasonable value for an area of high rainfall and low solar radiation.

\section{DISCUSSION OF WATER-BUDGET RESULTS}

The relations between water-budget components are summarized for various sub-areas for each scenario in tables 6 through 8 . The effect of irrigation was most significant in scenario II (1926-79) when irrigation was at the maximum for sugarcane (table 6). The mean evapotranspiration was four times what it was during natural scenario I. The mean evapotranspiration rate of $12 \mathrm{Mgal} / \mathrm{d}$ and the peak rate in June of $26 \mathrm{Mgal} / \mathrm{d}$ equal $0.18 \mathrm{in} / \mathrm{d}$ and $0.4 \mathrm{in} / \mathrm{d}$, respectively over the sugarcane area. These rates are supported by lysimeter data (Campbell and others, 1959) from other sugarcane fields on Maui where average and peak use rates were $0.23 \mathrm{in} / \mathrm{d}$ and $0.34 \mathrm{in} / \mathrm{d}$, respectively. The mean actual evapotranspiration/pan evaporation ratio of 86 percent in the sugarcane area likewise is reasonable given the extreme water-use rate of the crop for maximum production. If the rainfall, mean direct runoff for this area (about $1 \mathrm{Mgal} / \mathrm{d}$ or 12 percent of rainfall), and maximum soil-moisture storage values are reasonable, then the validity of the calculated evapotranspiration values supports a mean ground-water recharge of $19 \mathrm{Mgal} / \mathrm{d}$ for scenario II. Ground-water recharge during scenario II was more than six times what it was estimated to be in the natural scenario with no irrigation. Because the water-budget for the sugarcane area plays a dominant role in the budget for the entire basal area (table 7, scenario II) the latter values are similarly reasonable.

After 1979, most of the sugarcane acreage shifted from sugarcane cultivation to macadamia nut trees and pineapple during scenarios III and IV (fig. 6 and table 8 ). The crop changes dictated decreases in irrigation resulting in striking decreases in evapotranspiration, especially during the summer months, and in recharge, particularly during the winter months compared with scenario II. The peak actual evapotranspiration rate of $26 \mathrm{Mgal} / \mathrm{d}$ in June for scenario II decreased to 11 $\mathrm{Mgal} / \mathrm{d}$ in both July and September in scenario III and to $6 \mathrm{Mgal} / \mathrm{d}$ in several months in scenario IV. Peak recharge rates decreased from $32 \mathrm{Mgal} / \mathrm{d}$ in February during scenario II to $16 \mathrm{Mgal} / \mathrm{d}$ and $10 \mathrm{Mgal} / \mathrm{d}$ in January during scenarios III and IV, respectively. Evapotranspiration during the winter months and groundwater recharge volumes for scenario IV are nearly the same in the agricultural field areas as they were under natural conditions, scenario I.

For the entire Iao area, the strongest seasonality in evapotranspiration and recharge is during the most heavily irrigated scenario II. The percentage of water (rainfall and irrigation) in the budget that is apportioned to evapotranspiration reaches a high of 68 percent in

Table 5. Water-budget components for high-level ground-water area, lao area, Maui, Hawaii

[Scenario I is natural, scenario II is 1926-1979, scenario III is 1980-85, and scenario IV is 1986-1995. AII values are in million gallons per day. The sum of rainfall plus irrigation minus direct runoff, actual evapotranspiration, and recharge may not equal zero because of rounding. The mean is calculated as the sum of monthly values divided by 12 . There is no change in values among scenarios]

\begin{tabular}{llccccccccccccc}
\hline $\begin{array}{l}\text { Water-budget } \\
\text { component }\end{array}$ & Scenario & Jan. & Feb. & Mar. & Apr. & May & June & July & Aug. & Sept. & Oct. & Nov. & Dec. & Mean \\
\hline Rainfall & I,II,III,IV & 91 & 92 & 109 & 99 & 71 & 32 & 60 & 64 & 51 & 59 & 99 & 83 & 76 \\
Irrigation & I,II,III,IV & 0 & 0 & 0 & 0 & 0 & 0 & 0 & 0 & 0 & 0 & 0 & 0 & 0 \\
Direct runoff & I,II,III,IV & 43 & 37 & 57 & 57 & 38 & 26 & 36 & 28 & 24 & 33 & 40 & 40 & 38 \\
Pan evaporation & I,II,III,IV & 11 & 13 & 11 & 11 & 18 & 55 & 23 & 23 & 30 & 18 & 12 & 13 & 20 \\
$\begin{array}{c}\text { Actual evapo- } \\
\text { transpiration }\end{array}$ & I,II,III,IV & 11 & 13 & 11 & 11 & 16 & 11 & 14 & 14 & 15 & 17 & 12 & 13 & 13 \\
Recharge & I,II,III,IV & 36 & 43 & 39 & 31 & 23 & 0.07 & 7 & 21 & 14 & 7 & 40 & 31 & 24 \\
\hline
\end{tabular}


June and a low of 14 percent in both January and March (table 9). A less striking range of evapotranspiration is seen in scenarios III and IV, 57 to 15 percent and 48 to 16 percent of the budget, respectively. Recharge shows a conversely strong seasonality in scenario II, with the highest ratios in the winter at 57 percent in February, and the lowest, less than 1 percent, during the summer, in June. All four scenarios have similarly wide ranges in recharge from winter to summer months.

Table 10 summarizes the disposition of the waterbudget components for the entire Iao study area. The volume of runoff, evapotranspiration, or ground-water recharge is divided by the sum of rainfall plus irrigation. It should be noted that the volume of runoff is the same for all scenarios. However, in this table the runoff apportionment changes with the scenarios because of the increase in the denominator values from irrigation in scenarios II, III, and IV. Area-wide, the relatively small proportion (12 to 15 percent) of the total area over which irrigation water was applied resulted in only a 2 point increase in the evapotranspiration ratios for the highest irrigation scenarios II and III and only a 7 point increase in the recharge ratio between scenario II and scenario $I$, in which there is no irrigation. During irrigation scenarios II and III, the water-budget components for the study area are apportioned roughly at about 35 percent runoff, 27 percent evapotranspiration, and about 39 percent recharge. During periods of no or low irrigation, scenarios I and IV, the apportionment of evapotranspiration and recharge decreases slightly to 25 and 35 percent, respectively.

Comparison with results of previous studies.-Water-budget results are compared in table 11 with

Table 6. Water-budget components for sugarcane area, lao area, Maui, Hawaii

[All values are in million gallons per day. Scenario I is natural, scenario II is 1926-1979, scenario III is 1980-85, and scenario IV is 1986-1995. The sum of rainfall plus irrigation minus direct runoff, actual evapotranspiration, and recharge may not equal zero because of rounding. The mean is calculated as the sum of monthly values divided by 12 . Acreage decreased from 2,245 acres in scenario II to about 940 acres in scenario III, and to about 130 acres in scenario IV]

\begin{tabular}{|c|c|c|c|c|c|c|c|c|c|c|c|c|c|c|}
\hline $\begin{array}{l}\text { Water-budget } \\
\text { component }\end{array}$ & Scenario & Jan. & Feb. & Mar. & Apr. & May & June & July & Aug. & Sept. & Oct. & Nov. & Dec. & Mean \\
\hline \multirow[t]{3}{*}{ Rainfall } & I,II & 12 & 11 & 11 & 9 & 3 & 1 & 2 & 3 & 2 & 6 & 8 & 13 & 7 \\
\hline & III & 5 & 4 & 4 & 3 & 1 & 0.38 & 0.61 & 0.83 & 0.66 & 2 & 3 & 5 & 2 \\
\hline & IV & 0.56 & 0.48 & 0.51 & 0.34 & 0.17 & 0.08 & 0.11 & 0.09 & 0.14 & 0.32 & 0.34 & 0.67 & 0.32 \\
\hline \multirow{4}{*}{ Irrigation } & I & 0 & 0 & 0 & 0 & 0 & 0 & 0 & 0 & 0 & 0 & 0 & 0 & 0 \\
\hline & II & 24 & 27 & 24 & 25 & 24 & 25 & 24 & 24 & 25 & 24 & 25 & 24 & 25 \\
\hline & III & 8 & 9 & 8 & 8 & 8 & 8 & 8 & 8 & 8 & 8 & 8 & 8 & 8 \\
\hline & IV & 1 & 1 & 1 & 1 & 1 & 1 & 1 & 1 & 1 & 1 & 1 & 1 & 1 \\
\hline \multirow{4}{*}{$\begin{array}{l}\text { Direct } \\
\text { runoff }\end{array}$} & I & 1 & 1 & 1 & 1 & 0.37 & 0.16 & 0.27 & 0.31 & 0.29 & 0.67 & 0.93 & 2 & 0.81 \\
\hline & II & 1 & 1 & 1 & 1 & 0.37 & 0.16 & 0.27 & 0.31 & 0.29 & 0.67 & 0.93 & 2 & 0.81 \\
\hline & III & 0.54 & 0.47 & 0.46 & 0.37 & 0.13 & 0.05 & 0.07 & 0.10 & 0.08 & 0.22 & 0.30 & 0.57 & 0.28 \\
\hline & IV & 0.07 & 0.06 & 0.06 & 0.04 & 0.02 & 0.01 & 0.01 & 0.01 & 0.02 & 0.04 & 0.04 & 0.08 & 0.04 \\
\hline \multirow[t]{3}{*}{ Pan evaporation } & I,II & 4 & 5 & 4 & 6 & 16 & 42 & 23 & 20 & 23 & 9 & 7 & 4 & 14 \\
\hline & III & 1 & 2 & 2 & 2 & 6 & 19 & 10 & 8 & 10 & 3 & 2 & 1 & 6 \\
\hline & IV & 0.2 & 0.3 & 0.3 & 0.4 & 0.8 & 2 & 1 & 1 & 1 & 0.4 & 0.4 & 0.2 & 0.7 \\
\hline \multirow{4}{*}{$\begin{array}{l}\text { Actual evapo- } \\
\text { transpiration }\end{array}$} & I & 4 & 4 & 4 & 5 & 4 & 1 & 2 & 2 & 2 & 4 & 5 & 3 & 3 \\
\hline & II & 4 & 5 & 4 & 6 & 16 & 26 & 22 & 19 & 22 & 9 & 7 & 4 & 12 \\
\hline & III & 1 & 2 & 2 & 2 & 6 & 9 & 8 & 7 & 8 & 3 & 2 & 1 & 4 \\
\hline & IV & 0.23 & 0.33 & 0.28 & 0.40 & 0.78 & 1 & 1 & 1 & 0.98 & 0.41 & 0.40 & 0.19 & 0.62 \\
\hline \multirow[t]{4}{*}{ Recharge } & I & 7 & 6 & 6 & 4 & 0.03 & 0 & 0.01 & 0.01 & 0.01 & 0.92 & 2 & 6 & 3 \\
\hline & II & 31 & 32 & 30 & 27 & 12 & 0.01 & 5 & 7 & 6 & 20 & 25 & 30 & 19 \\
\hline & III & 11 & 11 & 10 & 9 & 3 & 0 & 0.21 & 2 & 0.41 & 6 & 8 & 10 & 6 \\
\hline & IV & 1 & 1 & 1 & 1 & 0.47 & 0 & 0.15 & 0.05 & 0.28 & 0.96 & 1 & 1 & 0.78 \\
\hline
\end{tabular}


Table 7. Water-budget components for the basal ground-water area of the lao area, Maui, Hawaii

[Scenario I is natural conditions, scenario II is I926-79, scenario III is 1980-85, scenario IV is 1986-95. All values are in million gallons per day. The sum of rainfall plus irrigation minus direct runoff, actual evapotranspiration, and recharge may not equal zero because of rounding. The mean is calculated as the sum of monthly values divided by 12 ]

\begin{tabular}{lcrrrrrrrrrrrrrr}
\hline $\begin{array}{l}\text { Water-budget } \\
\text { component }\end{array}$ & Scenario & Jan. & Feb. & Mar. & Apr. & May & June & July & Aug. & Sept. & Oct. & Nov. & Dec. & Mean \\
\hline Rainfall & I,II,III,IV & \multicolumn{1}{c}{45} & 40 & 37 & 35 & 13 & 5 & 9 & 10 & 9 & 20 & 31 & 44 & 25 \\
Irrigation & & & & & & & & & & & & & & \\
& I & 0 & 0 & 0 & 0 & 0 & 0 & 0 & 0 & 0 & 0 & 0 & 0 & 0 \\
& II & 24 & 27 & 24 & 25 & 24 & 25 & 24 & 24 & 25 & 24 & 25 & 24 & 25 \\
& III & 9 & 9 & 9 & 9 & 9 & 9 & 9 & 9 & 9 & 9 & 9 & 9 & 9 \\
& IV & 3 & 3 & 3 & 3 & 3 & 3 & 3 & 3 & 3 & 3 & 3 & 3 & 3 \\
Direct runoff & I,II,II,IV & 5 & 5 & 4 & 4 & 1 & 0.58 & 1 & 1 & 1 & 2 & 4 & 5 & 3 \\
& & & & & & & & & & & & & & \\
Pan evaporation & I,II,III,IV & 13 & 18 & 16 & 20 & 49 & 141 & 74 & 67 & 76 & 31 & 21 & 13 & 45 \\
& & & & & & & & & & & & & & \\
Actual evapo- & I & 12 & 15 & 13 & 15 & 16 & 5 & 8 & 9 & 8 & 14 & 15 & 12 & 12 \\
transpiration & II & 12 & 16 & 14 & 16 & 28 & 30 & 27 & 26 & 27 & 19 & 17 & 12 & 20 \\
& III & 12 & 16 & 14 & 16 & 21 & 14 & 16 & 16 & 17 & 18 & 17 & 12 & 16 \\
& IV & 12 & 15 & 14 & 16 & 18 & 8 & 10 & 11 & 10 & 16 & 16 & 12 & 13 \\
Recharge & & & & & & & & & & & & & & \\
& I & 28 & 22 & 20 & 17 & 2 & 0.01 & 0.09 & 0.08 & 0.09 & 3 & 9 & 23 & 10 \\
& II & 52 & 48 & 44 & 41 & 14 & 0.02 & 5 & 7 & 6 & 22 & 31 & 47 & 26 \\
& III & 37 & 31 & 28 & 25 & 5 & 0.01 & 0.29 & 2 & 0.48 & 8 & 16 & 32 & 15 \\
& IV & 30 & 24 & 22 & 19 & 2 & 0.08 & 0.32 & 0.21 & 0.45 & 3 & 10 & 25 & 11 \\
\hline
\end{tabular}

Table 8. Water-budget components for agricultural fields in the lao area, Maui, Hawaii

[Scenario I is natural, scenario II is 1926-1979, scenario III is 1980-85, and scenario IV is 1986-1995. All values are in million gallons per day. The sum of rainfall plus irrigation minus direct runoff, actual evapotranspiration, and recharge may not equal zero because of rounding. The mean is calculated as the sum of monthly values divided by 12 ]

\begin{tabular}{|c|c|c|c|c|c|c|c|c|c|c|c|c|c|c|}
\hline $\begin{array}{c}\text { Water-budget } \\
\text { component }\end{array}$ & Scenario & Jan. & Feb. & Mar. & Apr. & May & June & July & Aug. & Sept. & Oct. & Nov. & Dec. & Mean \\
\hline$\overline{\text { Rainfall }}$ & I,II,III,IV & 12 & 11 & 11 & 9 & 3 & 1 & 2 & 3 & 2 & 6 & 8 & 13 & 7 \\
\hline \multirow[t]{4}{*}{ Irrigation } & I & 0 & 0 & 0 & 0 & 0 & 0 & 0 & 0 & 0 & 0 & 0 & 0 & 0 \\
\hline & II & 24 & 27 & 24 & 25 & 24 & 25 & 24 & 24 & 25 & 24 & 25 & 24 & 25 \\
\hline & III & 9 & 9 & 9 & 9 & 9 & 9 & 9 & 9 & 9 & 9 & 9 & 9 & 9 \\
\hline & IV & 3 & 3 & 3 & 3 & 3 & 3 & 3 & 3 & 3 & 3 & 3 & 3 & 3 \\
\hline $\begin{array}{l}\text { Direct } \\
\text { runoff }\end{array}$ & I,II,III,IV & 1 & 1 & 1 & 1 & 0.37 & 0.16 & 0.27 & 0.31 & 0.29 & 0.67 & 0.93 & 2 & 0.81 \\
\hline Pan evaporation & I,II,III,IV & 4 & 5 & 4 & 6 & 16 & 42 & 23 & 20 & 23 & 9 & 7 & 4 & 14 \\
\hline \multirow{4}{*}{$\begin{array}{l}\text { Actual evapo- } \\
\text { transpiration }\end{array}$} & I & 4 & 4 & 4 & 5 & 4 & 1 & 2 & 2 & 2 & 4 & 5 & 3 & 3 \\
\hline & II & 4 & 5 & 4 & 6 & 16 & 26 & 22 & 19 & 22 & 9 & 7 & 4 & 12 \\
\hline & III & 4 & 5 & 4 & 6 & 9 & 10 & 11 & 10 & 11 & 8 & 6 & 4 & 7 \\
\hline & IV & 4 & 5 & 4 & 6 & 6 & 4 & 4 & 5 & 5 & 6 & 6 & 4 & 5 \\
\hline \multirow[t]{4}{*}{ Recharge } & I & 7 & 6 & 6 & 4 & 0.03 & 0 & 0.01 & 0.01 & 0.01 & 0.92 & 2 & 6 & 3 \\
\hline & II & 31 & 32 & 30 & 27 & 12 & 0.01 & 5 & 7 & 6 & 20 & 25 & 30 & 19 \\
\hline & III & 16 & 15 & 14 & 12 & 4 & 0 & 0.21 & 2 & 0.41 & 6 & 9 & 15 & 8 \\
\hline & IV & 10 & 8 & 8 & 5 & 0.76 & 0.07 & 0.24 & 0.14 & 0.38 & 1 & 3 & 8 & 4 \\
\hline
\end{tabular}


water budgets from previous investigations. The water budgets are not directly comparable because of differences in areas for which they were calculated. Therefore, several columns are included in the table indicating the apportionment of the budget components and the values of the components per unit area. The presentation highlights the comparative magnitude of the effects of assumptions made in the water-budget calculations on the water-budget results. Following results from this study, the next results listed (Commission on Water Resource Management, 1990) are for an area described as the basal part of the Iao area, not including caprock areas. Next are budget results from a study (Yamanaga and Huxel, 1970) of Iao Valley only, which addresses only the "permeable volcanic slopes" of that area. Caskey's (1968) study addressed the eastern slopes of the West Maui Mountain including the part of Iao Valley for which runoff was measured at a gaging station (discontinued in 1915). Caskey created a rainfall map from data collected at 25 stations in the west Maui area. Because the budgets Caskey calculated for this part of Iao Valley and other west Maui basins did not have enough water from rainfall to satisfy runoff and estimated evapotranspiration demands, Caskey reasoned that the rainfall values from his map must be too low. Caskey therefore devised a method to augment rainfall and calculated an increase of $30.7 \mathrm{Mgal} / \mathrm{d}$ of rainfall to the Iao Valley area. Caskey assumed the entire additional rainfall was dispersed as ground-water discharge, and therefore, increased the estimate of ground-water recharge from the original $1.6 \mathrm{Mgal} / \mathrm{d}$ to 32.3 Mgal/d. A comparison of the result from the present study for a part of the lao area thought to be comparable to the area from the Commission on Water Resource Management (1990) shows a discrepancy in area. The boundaries of the area in the 1990 study were

Table 9. Monthly water-budget ratios for four model scenarios for the lao area, Maui, Hawaii

[Values, in percent, represent the fractional disposition of inflows (rainfall and irrigation) among the outflow components (runoff, actual evapotranspiration, and recharge). Sum of runoff, actual evapotranspiration and recharge may not equal 100 percent due to rounding; I, natural scenario, II, 1926-79 scenario, III, 1980-85 scenario, IV, 1986-95 scenario; values were calculated by dividing the monthly values found in table 4, of direct runoff, for example, by the sum of the rainfall plus irrigation value for the respective scenario and month. There is no irrigation for scenario I]

\begin{tabular}{|c|c|c|c|c|c|c|c|c|c|c|c|c|c|}
\hline Ratio & Scenario & Jan. & Feb. & Mar. & Apr. & May & June & July & Aug. & Sept. & Oct. & Nov. & Dec. \\
\hline \multirow[t]{4}{*}{ Runoff } & I & 35 & 32 & 42 & 46 & 46 & 70 & 54 & 41 & 42 & 46 & 34 & 36 \\
\hline & II & 30 & 26 & 36 & 38 & 36 & 42 & 40 & 31 & 29 & 35 & 28 & 30 \\
\hline & III & 33 & 30 & 39 & 43 & 42 & 57 & 48 & 36 & 36 & 41 & 32 & 33 \\
\hline & IV & 34 & 31 & 41 & 45 & 45 & 65 & 52 & 39 & 40 & 44 & 33 & 35 \\
\hline \multirow{4}{*}{$\begin{array}{l}\text { Actual evapo- } \\
\text { transpiration }\end{array}$} & I & 17 & 21 & 16 & 19 & 38 & 43 & 32 & 31 & 38 & 39 & 21 & 20 \\
\hline & II & 14 & 18 & 14 & 17 & 41 & 68 & 46 & 41 & 49 & 35 & 19 & 17 \\
\hline & III & 16 & 21 & 15 & 19 & 40 & 57 & 40 & 36 & 46 & 39 & 20 & 19 \\
\hline & IV & 16 & 21 & 16 & 20 & 39 & 48 & 34 & 32 & 40 & 40 & 21 & 19 \\
\hline \multirow[t]{4}{*}{ Recharge } & I & 47 & 49 & 40 & 36 & 29 & 0.2 & 10 & 28 & 23 & 13 & 38 & 43 \\
\hline & II & 55 & 57 & 49 & 45 & 33 & 0.1 & 12 & 29 & 24 & 28 & 46 & 53 \\
\hline & III & 50 & 52 & 44 & 39 & 30 & 0.2 & 9 & 28 & 20 & 17 & 40 & 47 \\
\hline & IV & 47 & 50 & 41 & 36 & 29 & 0.4 & 10 & 27 & 22 & 12 & 38 & 44 \\
\hline
\end{tabular}

Table 10. Annual water-budget ratios for four model scenarios, lao area, Maui, Hawaii

[Values, in percent, represent the fractional disposition of inflows (rainfall and irrigation) among the outflow components (runoff, actual evapotranspiration, and recharge). Sum of runoff, actual evapotranspiration and recharge may not equal 100 percent due to rounding; I, natural scenario; II, 1926-79 scenario; III, 1980-85 scenario; IV, 1986-95 scenario; values were calculated by dividing the mean values found in table 4, of direct runoff, for example, by the sum of the mean rainfall and mean irrigation for the respective scenario. There is no irrigation for scenario I]

\begin{tabular}{cccc}
\hline Scenario & Runoff & Actual evapotranspiration & Recharge \\
I & 41 & 25 & 34 \\
II & 33 & 27 & 41 \\
III & 38 & 27 & 37 \\
IV & 40 & 25 & 35 \\
\hline
\end{tabular}


not clearly presented, and therefore the inconsistency is not surprising.

The rainfall maps (Giambelluca and others, 1986) used in the present water-budget calculations were not available when the Yamanaga and Huxel (1970) and Caskey (1968) reports were prepared. Both maps used in these previous reports show considerably more rainfall over the high-level part of the study area, than the present maps. The various estimates in rainfall directly affect the other water-budget components. Although the same rainfall maps were used for the Commission on Water Resource Management (1990) report and the present study, comparable rainfall values were not calculated. Commission on Water Resource Management (1990) indicates some "weighted average" was applied to the rainfall which, over the given larger area, may be expected to yield a larger rainfall value compared with the value from a slightly smaller area in the present study.

All the previous water-budgets were calculated on an annual basis. Evapotranspiration was estimated as potential (maximum) evapotranspiration which overestimates evapotranspiration and, in turn, minimizes the estimate of ground-water recharge. Again, a comparison of Commission on Water Resource Management (1990) and the present study shows the result of assuming potential evapotranspiration rates: the evapotranspi- ration rate in Commission on Water Resource Management (1990) is almost twice the rate estimated for a similar area in the present study. Similarly, the estimate of recharge from Commission on Water Resource Management (1990) is about half the recharge value estimated in the present study.

Limitations of the model.--The water-budget results indicate limitations of the water-budget model. Three aspects to note are the regional nature of the model, the average values of all input data, and the monthly time-step of the calculations. For part of the Iao area, the runoff calculations are regionalized by applying average relations, determined from an individual basin, over large areas. The available-water capacity and the calculated maximum soil-moisture storage of the soil types in the Iao area are important components in the water-budget model, because they govern ground-water recharge and evapotranspiration. The data used to calculate these components come from individual soil-core profiles that are regionalized for the soil series. Similarly, for irrigated areas, irrigation water was applied homogeneously over the area in the budget, with no adjustments for high and low rainfall areas or for high or low mean rainfall during the month.

All rainfall, direct runoff, pan evaporation, and soil data are averages that eliminate the extremes that occur in nature over time and varying terrain. The error asso-

Table 11. Water-budget estimates from various investigations, lao area, Maui, Hawaii [Mgal/d, million gallons per day; $\mathrm{mi}^{2}$, square miles; ET, evapotranspiration; the difference of rainfall minus direct runoff, [actual] evapotranspiration, and recharge may not equal zero because of rounding]

\begin{tabular}{|c|c|c|c|c|c|c|c|c|c|c|c|c|}
\hline \multirow[b]{2}{*}{ Reference } & \multirow[b]{2}{*}{$\begin{array}{l}\text { Area } \\
\left(\mathrm{mi}^{2}\right)\end{array}$} & \multicolumn{4}{|c|}{ (Mgal/d) } & \multicolumn{4}{|c|}{$\left(\right.$ Mgal/d//mi $\left.{ }^{2}\right)$} & \multicolumn{3}{|c|}{ Percentage of rainfall } \\
\hline & & Rainfall & $\begin{array}{l}\text { Direct } \\
\text { runoff }\end{array}$ & ET & Recharge & Rainfall & $\begin{array}{l}\text { Direct } \\
\text { runoff }\end{array}$ & ET & Recharge & $\begin{array}{l}\text { Direct } \\
\text { runoff }\end{array}$ & ET & Recharge \\
\hline This study & 24.69 & 100 & 41 & 25 & 34 & 4.05 & 1.66 & 1.01 & 1.38 & 41 & 25 & 34 \\
\hline This study ${ }^{2}$ & 16.15 & 87 & 40 & 18 & 29 & 5.39 & 2.48 & 1.11 & 1.8 & 46 & 21 & 33 \\
\hline $\begin{array}{l}\text { Commission on } \\
\text { Water Resource } \\
\text { Management (1990) }\end{array}$ & 17.81 & 82 & 33 & 34 & 15 & 4.6 & 1.85 & 1.91 & 0.84 & 40 & 41 & 18 \\
\hline $\begin{array}{l}\text { Yamanaga and Huxel } \\
(1970)\end{array}$ & 9.2 & 95 & 50 & 10 & 35 & 10.33 & 5.43 & 1.09 & 3.8 & 53 & 11 & 37 \\
\hline Caskey $(1968)^{3}$ & 6.02 & 52.63 & 38.7 & 12.33 & 1.6 & 8.74 & 6.43 & 2.05 & 0.27 & 74 & 23 & 3 \\
\hline Caskey $(1968)^{4}$ & 6.02 & 83.33 & 38.7 & 12.33 & 32.3 & 13.84 & 6.43 & 2.05 & 5.37 & 46 & 15 & 39 \\
\hline
\end{tabular}

${ }^{1}$ For entire Iao area, for natural conditions, scenario I

${ }^{2}$ For area thought to be comparable to area used in Commission on Water Resource Management (1990), Scenario IV values

${ }^{3}$ Iao drainage basin gaged at discontinued station 16604000

${ }^{4}$ Iao drainage basin with "augmented rainfall" 
ciated with these average data is likely compounded by the budget accounting with a monthly time interval. Although this monthly budget estimates evapotranspiration more accurately than assuming the maximum evapotranspiration rate, in reality, the components of the water budget are interacting on the order of minutes and hours within small areas. The monthly time interval does not allow for filling and draining of the soil-moisture storage more than once a month. Therefore, the entire month's rainfall is modeled as a single event, in many cases more than filling the soil-moisture storage and thereby producing recharge. This process may overestimate recharge, particularly in the wet upland areas. The comparison of pan evaporation and calculated evapotranspiration showed evapotranspiration occurring at reasonable rates of 100 percent during the wet winter months and at about 65 percent of the mean pan rate. If all other budget components are similarly, reasonably estimated, it follows that the recharge estimate is also reasonable. In irrigated areas, the soil-moisture storage value was set equal to the maximum evapotranspiration value. This adjustment caused evapotranspiration to occur at the maximum rate if water was available. Assuming other budget components are reasonably estimated in the irrigated areas, recharge would not be overestimated. Although daily, watershed-scale, temporal data could more accurately determine evapotranspiration and ground-water recharge, these data are not available, and a monthly budget for the area is the time interval the available data warrant.

\section{SUMMARY AND CONCLUSIONS}

Land use has changed during the past 70 years in the Iao area of Maui. Extensive agricultural development has occurred since the late 1800's when streamflow was diverted to irrigate thousands of acres of sugarcane by way of furrow methods. Until the late 1970 's sugarcane was the only plantation crop being cultivated. During the 1980's crops were diversified in the area. The irrigation system was replaced by more efficient drip and micro-sprinkler systems and several hundred acres of sugarcane were replaced with macadamia nut trees. From the mid-1980's until the present, most remaining sugarcane acreage has shifted to pineapple cultivation.
A preliminary step in understanding the groundwater system that has been tapped for water supply in the Iao area is the calculation of a water budget. A mean monthly water budget was developed to estimate ground-water recharge for four scenarios: natural conditions, and agricultural conditions during 1926-79, 1980-85, and 1986-95. These recharge estimates are integral to the understanding of the ground-water system over time and to the assessment of ground-water availability in the Iao area.

Rainfall in the Iao area ranges from about $30 \mathrm{in} / \mathrm{yr}$ along the coast near Waiehu to greater than $300 \mathrm{in} / \mathrm{yr}$ at the mountain crest at the northern end of the study area. Irrigation has varied over time, decreasing from a high of about $25 \mathrm{Mgal} / \mathrm{d}$ during 1926 to 1979 to about 3 Mgal/d during the 1986 to 1995 scenario.

Average ground-water recharge for 1986-95 conditions, estimated by the water-budget analysis, is about $36 \mathrm{Mgal} / \mathrm{d}$ for the Iao area. Average rainfall, irrigation, direct runoff, and evapotranspiration are $100 \mathrm{Mgal} / \mathrm{d}, 3$ $\mathrm{Mga} / \mathrm{d}$, $41 \mathrm{Mgal} / \mathrm{d}$, and $26 \mathrm{Mgal} / \mathrm{d}$, respectively. Average ground-water recharge was $51 \mathrm{Mgal} / \mathrm{d}$ during 192679 when irrigation averaged $25 \mathrm{Mgal} / \mathrm{d}$. Recharge was less (34 Mgal/d) in the natural scenario during which there was no agricultural irrigation.

\section{REFERENCES CITED}

Campbell, R.B., Chang, J.H., and Cox D.C., 1959, Evapotranspiration of sugar cane in Hawaii as measured by infield lysimeters in relation to climate: Proceeding of the 10th congress of the International Society of Sugarcane Technologists, p. 637-649.

Caskey, M.C., 1968, The recharge of the Waikapu aquifer, Maui: Honolulu, Hawaii, University of Hawaii, Masters thesis, $75 \mathrm{p}$.

Chang, J.H., 1968, Climate and agriculture: Chicago, Ill., Aldine Publishing Company, $304 \mathrm{p}$.

Commission on Water Resource Management, 1990, Water resources protection plan: prepared by George A.L. Yuen and Associates, Inc., for Department of Land and Natural Resources, State of Hawaii, 262 p.

Ekern, P.C., and Chang, J.H., 1985, Pan evaporation: State of Hawaii, 1894-1983: State of Hawaii, Department of Land and Natural Resources, Division of Water and Land Development, Report R74, 171 p.

Foote, D.E., Hill, E.L., Nakamura, Sakuichi, and Stephens, Floyd, 1972, Soil survey of the islands of Kauai, Oahu, 
Maui, Molokai, and Lanai, State of Hawaii: U.S. Department of Agriculture, Soil Conservation Service, $232 \mathrm{p}$.

Giambelluca, T.W., 1983, Water balance of the Pearl HarborHonolulu basin, Hawaii, 1946-1975: University of Hawaii Water Resources Research Center Technical Report 151, $151 \mathrm{p}$.

Giambelluca, T.W., Nullet, M.A., and Schroeder, T.A., 1986, Rainfall atlas of Hawaii: State of Hawaii, Department of Land and Natural Resources, Division of Water and Land Development, Report R76, 267 p.

Langbein, W.B., and Iseri, K.T., 1960, General introductions and hydrologic definitions, U.S. Geological Survey Water-Supply Paper 1541-A, 29 p.

Mather, J.R., 1978, The climatic water budget in environmental analysis: Lexington Books, Lexington, Massachusetts, $239 \mathrm{p}$.

Takasaki, K.J., 1978, Summary appraisals of the Nation's ground-water resources-Hawaii Region: U.S. Geological Survey Professional Paper 813-M, 29 p.

Thornthwaite, C.W., 1948, An approach toward a rational classification of climate: Geographical Review, v. 38, no. 1, p. 55-94.

Thornthwaite, C.W., and Mather, J.R., 1955, The water balance: Publications in climatology, v. 8, no. 1, p. 1-104.

Yamanaga, George and Huxel, C.J., 1970, Preliminary report on the water resources of the Wailuku area, Maui: State of Hawaii, Department of Land and Natural Resources, Division of Water and Land Development, Circular C61, $43 \mathrm{p}$. 